\title{
Overexpression of PGC-1 $\alpha$ enhances cell proliferation and tumorigenesis of HEK293 cells through the upregulation of Sp1 and Acyl-CoA binding protein
}

\author{
SUNG-WON SHIN ${ }^{1 *}$, SEONG-HOON YUN ${ }^{1 *}$, EUN-SEON PARK $^{1}$, \\ JIN-SOOK JEONG ${ }^{2}$, JONG-YOUNG KWAK ${ }^{1}$ and JOO-IN PARK ${ }^{1}$ \\ Departments of ${ }^{1}$ Biochemistry and ${ }^{2}$ Pathology, Dong-A University College of Medicine, Busan, Republic of Korea
}

Received November 10, 2014; Accepted December 29, 2014

DOI: $10.3892 /$ ijo.2015.2834

\begin{abstract}
Peroxisome proliferator-activated receptor $\gamma$ coactivator-1 $\alpha$ (PGC-1 $\alpha$ ), a coactivator interacting with multiple transcription factors, regulates several metabolic processes. Although recent studies have focused on the role of PGC-1 $\alpha$ in cancer, the underlying molecular mechanism has not been clarified. Therefore, we evaluated the role of PGC-1 $\alpha$ in cell proliferation and tumorigenesis using human embryonic kidney (HEK)293 cells and colorectal cancer cells. We established stable HEK293 cell lines expressing PGC-1 $\alpha$ and examined cell proliferation, anchorage-independent growth, and oncogenic potential compared to parental HEK293 cells. To identify the molecular PGC-1 $\alpha$ targets for increased cell proliferation and tumorigenesis, the GeneFishing ${ }^{\mathrm{TM}}$ DEG (differentially expressed genes) screening system was used. Western blot analysis and immunofluorescence staining were performed for a regulated gene product to confirm the results. Forced expression of PGC-1 $\alpha$ in HEK293 cells promoted cell proliferation and anchorage-independent growth in soft agar. In addition, HEK 293 cells that highly expressed PGC-1 $\alpha$ showed enhanced tumor formation when subcutaneously injected into the bilateral flanks of immunodeficient mice. The results of the GeneFishing DEG screening system identified one upregulated gene (Acyl-CoA binding protein; ACBP). Real-time RT-PCR, western blot analysis, and immunofluorescence staining showed that ACBP was markedly increased in HEK293 cells stably overexpressing PGC-1 $\alpha$ (PGC-1 $\alpha$-HEK293 cells) compared to those expressing an empty vector. In PGC-1 $\alpha$, $\mathrm{ACBP}$, and specificity protein 1 (Sp1) siRNA knockdown
\end{abstract}

Correspondence to: Professor Joo-In Park, Department of Biochemistry, Dong-A University College of Medicine, 32 Daesingongwon-ro, Seo-Gu, Busan 602-714, Republic of Korea

E-mail: jipark@dau.ac.kr

${ }^{*}$ Contributed equally

Key words: PGC-1 $\alpha$, cell proliferation, tumorigenesis, Acyl-CoA binding protein, $\mathrm{Sp} 1$ experiments in PGC-1 $\alpha$-HEK293 and SNU-C4 cells, we also observed inhibition of cell proliferation, reduced expression of antioxidant enzymes, and increased $\mathrm{H}_{2} \mathrm{O}_{2}$-induced reactive oxygen species production and apoptosis. These findings suggest that PGC-1 $\alpha$ may promote cell proliferation and tumorigenesis through upregulation of ACBP. We provide evidence that increased Sp1 expression might contribute to enhanced ACBP expression by PGC-1 $\alpha$. The current results also suggest that PGC-1 $\alpha$, whose expression is related to enhanced cell proliferation and tumorigenesis, may be a good candidate molecular target for cancer therapy.

\section{Introduction}

Many biological responses are regulated at the transcriptional level by interaction of transcription factors with transcriptional coactivators. For example, the peroxisome proliferator-activated receptor $\gamma(\operatorname{PPAR} \gamma)$ coactivator- $1 \alpha$ $(\mathrm{PGC}-1 \alpha)$ is a strong coactivator for PPAR $\gamma$, which is expressed in human heart, kidney, liver, and skeletal muscle, with only very low levels in white adipose tissue and small and large intestine (1). The PGC-1 family is integral to the coordinated activation of transcription complexes $(2,3)$ that regulate global responses such as mitochondrial biogenesis $(1,4)$ and tissue-specific responses such as adaptive thermogenesis (1), fatty acid oxidation $(5,6)$, hepatic gluconeogenesis $(7,8)$, fiber type switching in skeletal muscle (9), reactive oxygen species (ROS) metabolism (10), and clock gene expression (11). It also interacts with a number of other nuclear receptors such as glucocorticoid receptor (12), nuclear respiratory factor-1 (4), hepatocyte nuclear factor $4 \alpha$ (13), estrogen receptor $\alpha$ (8), PPAR $\alpha$ (5), retinoid $\mathrm{X}$ receptor (14), and estrogen-related receptor $\alpha$ (15). PGC-1 $\alpha$ contains a powerful autonomous transactivation domain at its N-terminus (aa 1-200) that binds two other coactivators with acetyltransferase activity, steroid receptor coactivator-1 (SRC-1) and CBP/p300 (11). PGC-1 $\alpha$ lacks acetyltransferase activity, thus requiring interaction with coactivators such as SRC-1 for regulation of target genes.

Recent studies have focused on the role of several coactivators in cancer. In particular, a role of PGC-1 $\alpha$ in cancer has been controversial. Some studies have shown that the expres- 
sion level of PGC-1 $\alpha$ decreases in certain cancer tissues such as breast $(16,17)$ and colon cancers $(18)$, but another study demonstrated that PGC-1 $\alpha$ overexpression induces apoptosis in ovarian cancer cells (19). In contrast, PGC-1 $\alpha$ is a suppressor of ROS (10), protecting cells from apoptosis in neuroblastoma cells (20) and promoting cell growth in prostate cancer cells (21), which suggests that PGC-1 $\alpha$ may be involved in cancer pathogenesis. Thus, to date, the effect of PGC-1 $\alpha$ in cell proliferation and tumorigenesis has not been completely clarified. In this study, therefore, the role of PGC- $1 \alpha$ in cell proliferation and tumorigenesis and the possible molecular mechanisms for its effect were evaluated using a stable human embryonic kidney (HEK)293 cell line expressing PGC-1 $\alpha$ and the GeneFishing DEG (differentially expressed genes) screening system (Seegene, Seoul, Korea).

\section{Materials and methods}

Cell preparations. The HEK293, human colon cancer HT-29 and SNU-C4, and mouse colon cancer CT-26 cells were obtained from the Korean Cell Line Bank (Seoul National University, Seoul, Korea) and cultured in Dulbecco's modified Eagle's medium (DMEM) supplemented with $10 \%$ fetal bovine serum (FBS), $100 \mathrm{U} / \mathrm{ml}$ penicillin, and $100 \mu \mathrm{g} / \mathrm{ml}$ streptomycin (Gibco, Carlsbad, CA, USA). Cultures were maintained in a humidified atmosphere of $95 \%$ air $/ 5 \% \mathrm{CO}_{2}$ at $37^{\circ} \mathrm{C}$.

Materials. 2', 7'-dichlorofluorescein diacetate (DCFDA) and carboxyfluorescein succinimidyl ester (CFSE) were obtained from Molecular Probes (Carlsbad, CA, USA). The Annexin V-FITC apoptosis detection kit was obtained from BD Biosciences (San Jose, CA, USA). Anti-PGC-1 $\alpha$ (sc-13067), anti-ACBP (sc-30190), anti-superoxide dismutase (SOD)-2 (sc-30080), anti-specificity protein 1 (Sp1) (sc-59), anti-rabbit IgG-FITC (sc-2012), anti-rabbit IgG-PE (sc-3739), and anti-mouse IgG-FITC (sc-2010) antibodies were purchased from Santa Cruz Biotechnology (Santa Cruz, CA, USA). Anti-catalase antibody (ab1877) was purchased from Abcam (Cambridge, UK). The anti-FLAG ${ }^{\circledR}$ (F7425), anti$\beta$-actin (A1978), anti-rabbit IgG (A0545), and anti-mouse IgG secondary antibodies (A9044) were purchased from Sigma-Aldrich (St. Louis, MO, USA). Unless stated otherwise, all other chemicals were purchased from Sigma.

Transfection and establishment of stable cell lines expressing the PGC-1 $\alpha$ vector. HEK 293 and CT-26 cells $\left(1 \times 10^{6}\right)$ were transfected with $4 \mu \mathrm{g}$ of pcDNA3.1-FLAG-PGC-1 $\alpha$ expression vector from Spiegelman or empty vector (pcDNA 3.1) using Lipofectamine 2000 (Invitrogen, Carlsbad, CA, USA) following the manufacturer's recommended procedure. After transfection, stable cell lines were established after G418 selection $(800 \mu \mathrm{g} / \mathrm{ml})$ for 14 days. Stable cell lines were cultured in DMEM supplemented with $10 \%$ FBS, $800 \mu \mathrm{g} / \mathrm{ml} \mathrm{G} 418$, $100 \mathrm{U} / \mathrm{ml}$ penicillin and $100 \mu \mathrm{g} / \mathrm{ml}$ streptomycin (Gibco). Cultures were maintained in a humidified atmosphere of $95 \%$ air $/ 5 \% \mathrm{CO}_{2}$ at $37^{\circ} \mathrm{C}$.

Real-time RT-PCR analysis. Total RNA was extracted using RNAeasy mini kits (Qiagen, Valencia, CA, USA). Reverse transcription was performed using the RevertAid First Strand cDNA synthesis kit with a random hexamer as the primer (Thermo Scientific, Chicago, IL, USA). Real-time reverse transcriptase PCR (RT-PCR) was carried out on total RNA from HEK293 and HEK293-PGC-1 $\alpha$ \#1 cells transfected with PGC-1 $\alpha$ and ACBP-specific or non-specific control small-interfering (si) RNA after $48 \mathrm{~h}$ on an ABI PRISM 7500 Sequence Detection System instrument (Applied Biosystems, Foster City, CA, USA). Each real-time RT-PCR was done in triplicate according to the manufacturer's instructions. TaqMan $^{\text {TM }}$ Gene expression assays [diazepam binding inhibitor (DBI)/ACBP (Hs01554584_m1)] were from Applied Biosystems. Quantification was based on a comparative $\Delta \mathrm{Ct}$ method using glyceraldehyde-3-phosphate dehydrogenase (GAPDH; Hs03929097_g1) as endogenous control.

Western blot analysis. Cells were harvested, washed with phosphate-buffered saline (PBS), and treated with lysis buffer containing $20 \mathrm{mmol} / \mathrm{l}$ Tris ( $\mathrm{pH} \mathrm{8.0),} 137 \mathrm{mmol} / \mathrm{l}$ $\mathrm{NaCl}, 10 \%$ glycerol, $1 \%$ Nonidet P-40, $10 \mathrm{mmol} / \mathrm{l}$ EDTA, $100 \mathrm{mmol} / 1 \mathrm{NaF}, 1 \mathrm{mmol} / 1$ phenylmethylsulfonyl fluoride and $10 \mathrm{mg} / \mathrm{ml}$ leupeptin. The lysates were centrifuged at $13,000 \mathrm{rpm}$ for $15 \mathrm{~min}$ and the concentration of protein in each lysate determined using Bio-Rad protein assay reagent (Bio-Rad, Richmond, CA, USA) following the manufacturer's suggested procedure. Then, 8, 10 or $12 \%$ SDS-PAGE was used to separate $30 \mu \mathrm{g}$ protein samples. Following electrophoresis, proteins were transferred to nitrocellulose membranes (Amersham Life Science, Inc., Arlington Heights, IL, USA). Blots were blocked overnight in $5 \%$ skim milk in PBS at $4^{\circ} \mathrm{C}$ and subsequently probed with primary antibody overnight. The blots were also probed with a monoclonal anti- $\beta$-actin antibody (Sigma) to be quantified as a relative loading control. Detection of specific proteins was carried out with enhanced chemiluminescence detection reagents (Amersham Life Science, Inc.) following the manufacturer's instructions. Bands were quantified using Image Studio Lite Ver 3.1. (LI-COR, Inc., Lincoln, NE, USA)

Cell counting. HEK293, PGC-1 $\alpha$-HEK293, CT-26, and PGC-1 $\alpha$-CT-26 cells were seeded at a density of $1 \times 10^{5} /$ well in a 6-well plate. PGC-1 $\alpha$-HEK293 and SNU-C4 cells transfected with siRNAs for PGC-1 $\alpha$, ACBP, Sp1, or non-specific control siRNA were seeded at a density of $1 \times 10^{5} /$ well in a 6 -well plate. After a 24-, 48- or 72-h culture, the cells were harvested by trypsinization using trypsin/EDTA and stained with trypan blue. The vital cells (those not stained with trypan blue) were counted under the microscope (Nikon Eclipse TS100; Nikon, Tokyo, Japan). Three independent experiments were carried out.

Cell proliferation assay. Cell proliferation was measured using the CFSE labeling assay as previously described (22). CFSE, which is used to fluorescently label live cells, is equally partitioned to daughter cells during division and can be used to measure cell proliferation. Briefly, cells were washed three times with PBS and incubated with $1 \mu \mathrm{M} \mathrm{CFSE} \mathrm{dye} \mathrm{(Molecular}$ Probes) for $15 \mathrm{~min}$. The cells were then washed again, incubated with fresh medium containing $10 \%$ FBS, and seeded in 6-well plates at a density of $1 \times 10^{5}$ cells/well. Cells were 
analyzed by flow cytometry (FACSCalibur; BD Biosciences) after culture for 24,48 or $72 \mathrm{~h}$. Each condition was performed in triplicate.

First-strand cDNA synthesis. Total RNA extracted from HEK293 cells and stable HEK293 cells expressing PGC-1 $\alpha$ was used for the synthesis of first-strand cDNA by reverse transcriptase. Reverse transcription was performed for $1.5 \mathrm{~h}$ at $42^{\circ} \mathrm{C}$ in a final reaction volume of $20 \mu \mathrm{l}$ containing $3 \mu \mathrm{g}$ of the purified total RNA, $4 \mu 1$ of $5 \mathrm{X}$ reaction buffer (Promega, Madison, WI, USA), $5 \mu 1$ of dNTPs (each $2 \mathrm{mM}$ ), $2 \mu 1$ of $10 \mu \mathrm{M}$ dT-ACP1 (5'-CTGTGAATGCTGCGACTACGATIIIIIT(18)-3'), $0.5 \mu 1$ of RNasin RNase Inhibitor (40 U/ $\mu 1$; Promega), and $1 \mu \mathrm{l}$ of Moloney murine leukemia virus reverse transcriptase (200 U/ $\mu 1$; Promega). First-strand cDNAs were diluted by the addition of $80 \mu$ l of ultra-purified water for the GeneFishing ${ }^{\mathrm{TM}}$ PCR and stored at $-20^{\circ} \mathrm{C}$ until use.

Annealing control primer (ACP)-based GeneFishing PCR. Differentially expressed genes were screened using the ACP-based PCR method (23) with the GeneFishing DEG kits (Seegene). Briefly, second-strand cDNA synthesis was conducted at $50^{\circ} \mathrm{C}$ during one cycle of first-stage PCR in a final reaction volume of $20 \mu \mathrm{l}$ containing 3-5 $\mu \mathrm{l}(\sim 50 \mathrm{ng})$ of diluted first-strand cDNA, $1 \mu \mathrm{l}$ of dT-ACP2 $(10 \mu \mathrm{M}), 1 \mu 1$ of $10 \mu \mathrm{M}$ arbitrary ACP and $10 \mu \mathrm{l}$ of $2 \mathrm{X}$ Master Mix (Seegene). The PCR protocol for second-strand synthesis was one cycle at $94^{\circ} \mathrm{C}$ for $1 \mathrm{~min}$, followed by $50^{\circ} \mathrm{C}$ for $3 \mathrm{~min}$ and $72^{\circ} \mathrm{C}$ for $1 \mathrm{~min}$. After second-strand DNA synthesis was completed, the second-stage PCR amplification protocol was 40 cycles of $94^{\circ} \mathrm{C}$ for $40 \mathrm{sec}$, followed by $65^{\circ} \mathrm{C}$ for $40 \mathrm{sec}$ and $72^{\circ} \mathrm{C}$ for $40 \mathrm{sec}$ and a 5 -min final extension at $72^{\circ} \mathrm{C}$. The amplified PCR products were separated on a $2 \%$ agarose gel stained with ethidium bromide. The amplified cDNA fragments with $>2$-fold differential band intensities were re-amplified and extracted from the gel by using the GeneClean II kit (Qbiogene, Solon, OH, USA), and directly sequenced with an ABI PRISM 310 Genetic Analyzer (Applied Biosystems).

Annexin V-PI staining assay. The extent of apoptosis was evaluated by Annexin V-FITC and flow cytometry as previously described (24). The Annexin V assay was used, in which Annexin was conjugated with FITC. Propidium iodide (PI) was used as counterstain. Briefly, cells were treated with $0.5,1$ or $2 \mathrm{mM} \mathrm{H}_{2} \mathrm{O}_{2}$ for $24 \mathrm{~h}$. After incubation, cells were harvested, washed with PBS (pH 7.4), centrifuged, and stained with Annexin V-FITC (BD Pharmingen, San Diego, CA, USA) and $2 \mu \mathrm{g} / \mathrm{ml}$ PI in binding buffer (10 mM HEPES, $\mathrm{pH}$ $7.4 / 140 \mathrm{mM} \mathrm{NaCl} / 2.5 \mathrm{mM} \mathrm{CaCl}_{2}$ ) for $15 \mathrm{~min}$ at $37^{\circ} \mathrm{C}$ in the dark. The samples were analyzed by flow cytometry using a FACScan flow cytometer. Data analysis was performed using CellQuest software (Becton-Dickinson, San Jose, CA, USA).

Soft-agar colony formation assay (25). HEK293 cells $\left(2.0 \times 10^{4}\right)$ overexpressing PGC-1 $\alpha$ or empty vector were suspended in $1 \mathrm{ml}$ of $0.3 \%$ agarose (Sigma) and then added to 1- of a 6-well plate with a foundation layer of $0.5 \%$ agarose in triplicate. Approximately $24 \mathrm{~h}$ later, the cells received an additional $1 \mathrm{ml}$ of growth medium before incubation for a further 14 days. Colonies were stained with $0.01 \%$ crystal violet and counted under the microscope (Nikon) in 20 fields of $\mathrm{x} 10$ magnification. Light microscopy images were captured under x100 magnification.

Effect of PGC-1 $\alpha$ on the tumor formation. All animal procedures and care were approved by the Institutional Animal Care and Usage Committee of Dong-A University. To determine the effect of PGC-1 $\alpha$ on tumor formation, viable HEK293 cells $\left(2 \times 10^{7}\right.$ cells $\left./ 100 \mu \mathrm{l}\right)$ overexpressing PGC- $1 \alpha$ or empty vector were subcutaneously injected into the bilateral flanks of 6- to 7-week-old female nu/nu immunodeficient BALB/c mice, respectively (Orient Bio Inc., Seongnam, Korea). Tumor size was measured daily with a caliper (calculated volume $=$ shortest diameter ${ }^{2} \mathrm{x}$ longest diameter/2). The mice were followed for tumor size and sacrificed on the 45th day. Tumors were resected, weighed, and frozen or fixed in formalin and paraffin-embedded for immunofluorescence staining.

Immunofluorescence staining. Cells were cultured on a Lab-Tek ${ }^{\circledR}$ Chamber Slide ${ }^{\mathrm{TM}}$ (Nalgen Nunc Inc., Rochester, NY, USA) and then fixed with $3 \%$ formaldehyde and permeabilized using $0.01 \%$ Triton X-100. After being blocked with $3 \%$ FBS for $30 \mathrm{~min}$, cells were incubated in primary antibody for $1 \mathrm{~h}$ followed by a fluorescence-labeled secondary antibody (Sigma) for $30 \mathrm{~min}$. Cells were then washed, mounted using glycerol, and analyzed by confocal microscope (Zeiss LSM 510 confocal microscope; Carl Zeiss Co., Ltd., Jena, Germany) using a 40x C-Apochromat objective. Negative control staining was performed with secondary antibodies alone.

Assessment of ROS production. ROS production was monitored by flow cytometry using carboxy- $\mathrm{H}_{2}$ DCFDA (Molecular Probes). PGC-1 $\alpha$-HEK 293 and SNU-C 4 cells transfected with siRNAs for PGC-1 $\alpha$, ACBP, or Sp1, or with non-specific control siRNA were washed twice with PBS to remove the extracellular compounds. $\mathrm{H}_{2}$ DCFDA $(100 \mu \mathrm{mol} / \mathrm{l})$ was added for an additional hour. Green fluorescence was excited using an argon laser and detected using a 525-nm band-pass filter by flow cytometric analysis.

siRNA transfection. The siRNA sequence used for the targeted silencing of PGC-1 $\alpha$, ACBP, or Sp1 was designed by Qiagen (GS10891), Dhamacon(L-006488-00-0005, Thermo Scientific, Chicago, IL, USA), or Santa Cruz (sc-29487), respectively. For transfection, cells were resuspended at $1.3 \times 10^{7} / 0.5 \mathrm{ml}$ in PBS and mixed with $4 \mathrm{nM}$ siRNA for PGC- $1 \alpha, 4 \mathrm{nM}$ siRNA for ACBP, or $4 \mathrm{nM}$ siRNA for Sp1, or with $4 \mathrm{nM}$ non-silencing siRNA using Lipofectamine 2000 (Invitrogen) following the manufacturer's procedure. After transfection, cells were cultured in 10\% FBS-supplemented DMEM for $48 \mathrm{~h}$. These cells were then used for cell proliferation, Annexin V-PI staining, assessment of ROS production, immunofluorescence staining, real-time RT-PCR and western blot analysis.

Immunoprecipitation. PGC-1 $\alpha$-HEK293 \#1 cells were washed in PBS and centrifuged at $1,000 \mathrm{rpm}$ for $5 \mathrm{~min}$ to harvest the cells. Ice-cold modified RIPA buffer $(50 \mathrm{mM}$ Tris-HCl, $\mathrm{pH} 7.4$, $1 \%$ NP-40, $0.25 \%$ Na-deoxycholate, $150 \mathrm{mM} \mathrm{NaCl}, 1 \mathrm{mM}$ EDTA, $1 \mathrm{mM}$ PMSF, $1 \mu \mathrm{g} / \mathrm{ml}$ each of aprotinin, leupeptin, 
and pepstatin, $1 \mathrm{mM} \mathrm{Na} \mathrm{VO}_{4}, 1 \mathrm{mM} \mathrm{NaF}$ ) was added to the cells, which were gently rocked on a rocker at $4{ }^{\circ} \mathrm{C}$ for $15 \mathrm{~min}$ for cell lysis. The lysate was centrifuged at $14,000 \mathrm{rpm}$ for $15 \mathrm{~min}$ at $4^{\circ} \mathrm{C}$ and pre-cleared by addition of $100 \mu \mathrm{l}$ of $50 \%$ Protein $\mathrm{G}$ sepharose bead slurry per $1 \mathrm{ml}$ of cell lysate. The supernatant was incubated with specific antibody overnight at $4^{\circ} \mathrm{C}$ with gentle rocking. The immune complex was captured by the addition of $100 \mu 1$ Protein $\mathrm{G}$ sepharose (Invitrogen). The sepharose beads were washed three times with $800 \mu \mathrm{l}$ ice-cold RIPA buffer and resuspended in $60 \mu \mathrm{l} 2 \mathrm{X}$ sample buffer, followed by elution through boiling. The immune complexes were fractionated on $10 \%$ SDS-PAGE followed by western blotting with appropriate antibodies.

Statistical analyses. Statistical analyses were done with the SPSS 21.0 statistical package for Windows (SPSS, Chicago, IL, USA). Data are expressed as mean values \pm standard deviation (SD). One-way ANOVA was used to determine whether there were significant differences in cell viability between PGC-1 $\alpha$-HEK293 \#1 cells, PGC-1 $\alpha$-HEK293 \#3 cells and HEK293 wild-type cells. Differences in tumor volumes between control HEK293 cell-injected and PGC-1 $\alpha$-HEK293 cell-injected groups were evaluated using the unpaired Student's t-test. Statistical significance was defined as $\mathrm{P}<0.05$.

\section{Results}

PGC-1 $\alpha$ accelerates proliferation of HEK293 and CT-26 cells. As a first step toward assessing the functional significance of PGC-1 $\alpha$ overexpression for growth of cells, HEK293 and CT-26 cells were transiently transfected with a FLAGtagged PGC-1 $\alpha$ expression vector or with the parental vector (pcDNA 3.1) and cultured with G418 (800 $\mu \mathrm{g} / \mathrm{ml})$ for 14 days. After that, several colonies were picked and amplified. Exogenously expressed PGC-1 $\alpha$ was detected by western blotting and immunofluorescence staining with antibodies against PGC-1 $\alpha$ and FLAG. As shown in Fig. 1A, the protein of PGC-1 $\alpha$ in PGC-1 $\alpha$-HEK293 \#1, PGC-1 $\alpha$-HEK293 \#3, and PGC-1 $\alpha$-CT-26 \#9 cells was increased compared to wild-type or pcDNA-transfected HEK293 and CT-26 cells. In addition, the exogenously expressed FLAG-tagged PGC-1 $\alpha$ (FLAG-PGC-1 $\alpha$ ) was detected in PGC-1 $\alpha$-transfected HEK293 (PGC-1 $\alpha$-HEK293 \#1 and \#3) and PGC-1 $\alpha$-transfected CT-26 (PGC-1 $\alpha$-CT-26 \#9) cells (Fig. 1B).

To investigate the effect of PGC- $1 \alpha$ overexpression on growth of HEK293 and CT-26 cells, cell viability and proliferation were determined by cell counting and CFSE labeling assays. As shown in Fig. 1C, the average number of cells in PGC-1 $\alpha$-transfected HEK293 and CT-26 cells (PGC-1 $\alpha$-HEK293 \#1 and \#3; 16.1 $\times 10^{5}$ and $15.5 \times 10^{5}$ at $72 \mathrm{~h}$, respectively; PGC-1 $\alpha-\mathrm{CT}-26 \# 9 ; 11.9 \times 10^{5}$ at $72 \mathrm{~h}$ ) was significantly higher than in wild-type HEK293 and CT-26 cells $\left(3.9 \times 10^{5}\right.$ at $72 \mathrm{~h} ; 7.9 \times 10^{5}$ at $72 \mathrm{~h}$, respectively). In addition, as expected, the number of cells with high fluorescence decreased with days in culture, so that the peak signals for PGC-1 $\alpha$-transfected cells (PGC-1 $\alpha$-HEK293 \#1, \#3 and PGC-1 $\alpha$-CT-26 cells) were shifted to the left compared to control cells (Fig. 1D). Thus, CFSE labeling analysis confirmed that PGC-1 $\alpha$ overexpression enhances cell proliferation of HEK293 and CT-26 cells.
Knockdown of PGC-1 $\alpha$ expression results in decreased cell proliferation of human colorectal cancer cells. The effect of PGC-1 $\alpha$ on cell proliferation was further investigated using siRNA transfection to knock down endogenous PGC-1 $\alpha$ expression in human colorectal cancer HT-29 and SNU-C4 cells. At $72 \mathrm{~h}$ after transfection, PGC-1 $\alpha$ expression was 40 and $53 \%$ lower than in wild-type or non-specific control siRNA-transfected HT-29 and SNU-C4 cells, respectively (Fig. 2A and B). Concurrently, proliferation of PGC-1 $\alpha$ siRNA-transfected HT-29 and SNU-C4 cells at 48 h posttransfection was significantly suppressed in comparison with that of untreated or non-silencing siRNA-transfected cells ( 37.2 and $33.5 \%$ reduction, respectively; $\mathrm{P}<0.01$ ) by cell counting and CFSE labeling (Fig. 2C). In addition, PGC-1 $\alpha$ siRNA transfection repressed cell proliferation by $26 \%$ at $48 \mathrm{~h}$ post-transfection in PGC-1 $\alpha$-HEK293 \#1 cells (Fig. 2C). Taken together, these results support an important role of PGC-1 $\alpha$ in the regulation of cell proliferation.

PGC-1 $\alpha$ promotes the oncogenic potential of HEK293 cells. Because anchorage-independent growth is considered to be an in vitro test for tumorigenesis, we assayed the effects of overexpression of PGC-1 $\alpha$ on the ability of HEK293 cells to form colonies in soft agar. As shown in Fig. 3A, overexpression of PGC-1 $\alpha$ in HEK293 cells resulted in a higher incidence of colony formation than observed following transfection with the empty vector (114. $4 \pm 13.6$ and $67.8 \pm 6.6, \mathrm{P}<0.001$, respectively). The cells transfected with empty vector formed no colonies during 14 days of culture whereas both cell lines expressing PGC-1 $\alpha$ formed a significantly high number of colonies of a large size (Fig. 3A). In addition, to confirm the impact of PGC-1 $\alpha$ overexpression on tumorigenesis, wild-type HEK293 cells or PGC-1 $\alpha$-overexpressing HEK293 cells were injected subcutaneously into bilateral flanks of immunodeficient $\mathrm{Balb} / \mathrm{c}$ mice, and tumor development and size were examined. Wild-type HEK293 cells formed tumors at a low percentage $(6.67 \pm 6.67 \%)$ whereas the matched PGC-1 $\alpha-H E K 293$ cells (PGC-1 $\alpha$-HEK293 \#1 and PGC-1 $\alpha$-HEK293 \#3) formed tumors in $76.67 \pm 8.82$ and $60.00 \pm 15.30 \%$ of mice, respectively (Fig. 3B and C). In addition, the average tumor size in mice with PGC-1 $\alpha$-HEK293 \#1 $\left(652.1 \pm 263.5 \mathrm{~mm}^{3}\right)$ was larger than in mice with PGC-1 $\alpha$-HEK293 \#3 $\left(217.3 \pm 75.9 \mathrm{~mm}^{3}\right)$, suggesting that the expression level of PGC- $1 \alpha$ is related to tumor growth. Furthermore, the presence of tumor cells was confirmed by hematoxylin and eosin staining (Fig. 3D). Thus, these data suggest that PGC-1 $\alpha$ overexpression dramatically enhances the tumorigenic capacity of HEK293 cells in Balb/c nude mice.

Decreased sensitivity to oxidative stress in PGC-1 $\alpha$ overexpressing HEK293 cells. Previous studies have demonstrated that PGC-1 $\alpha$ expression leads to expression of antioxidants such as SOD and catalase $(10,26)$ and provided evidence that PGC- $1 \alpha$ can protect neuroblastoma cells from $\mathrm{H}_{2} \mathrm{O}_{2}$-mediated cell death (10). In this study, to evaluate the role of PGC-1 $\alpha$ in providing a defense against oxidative stress, wild-type HEK293 and PGC-1 $\alpha$-overexpressing HEK293 cells were treated with various concentrations of $\mathrm{H}_{2} \mathrm{O}_{2}$ for $24 \mathrm{~h}$; the extent of apoptosis was determined using Annexin V-PI staining. Approximately $72.7 \%$ of the empty vector-expressing 
A

B

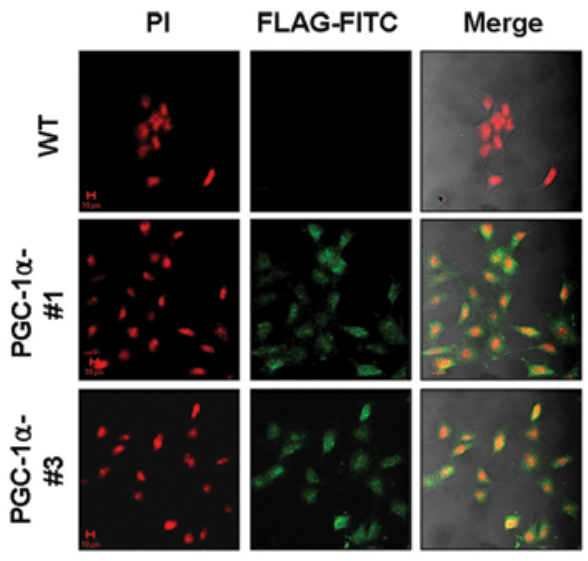

CT-26

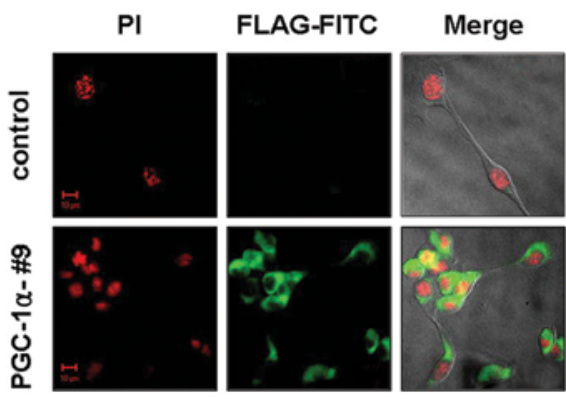

CT-26
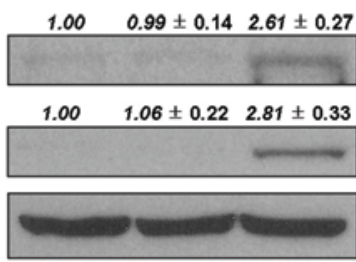

WT pcDNA $\frac{\# 9}{\text { PGC-1 } 1 \alpha}$

C

HEK293

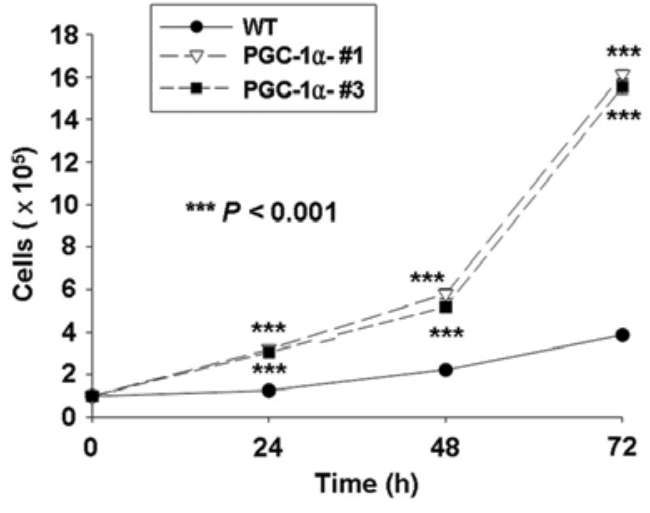

\section{CT-26}

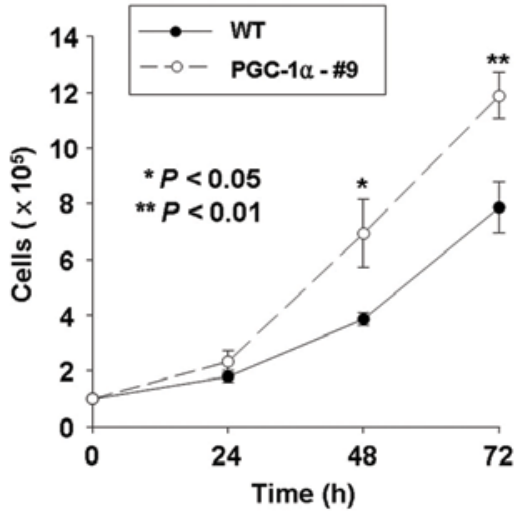

D

ص
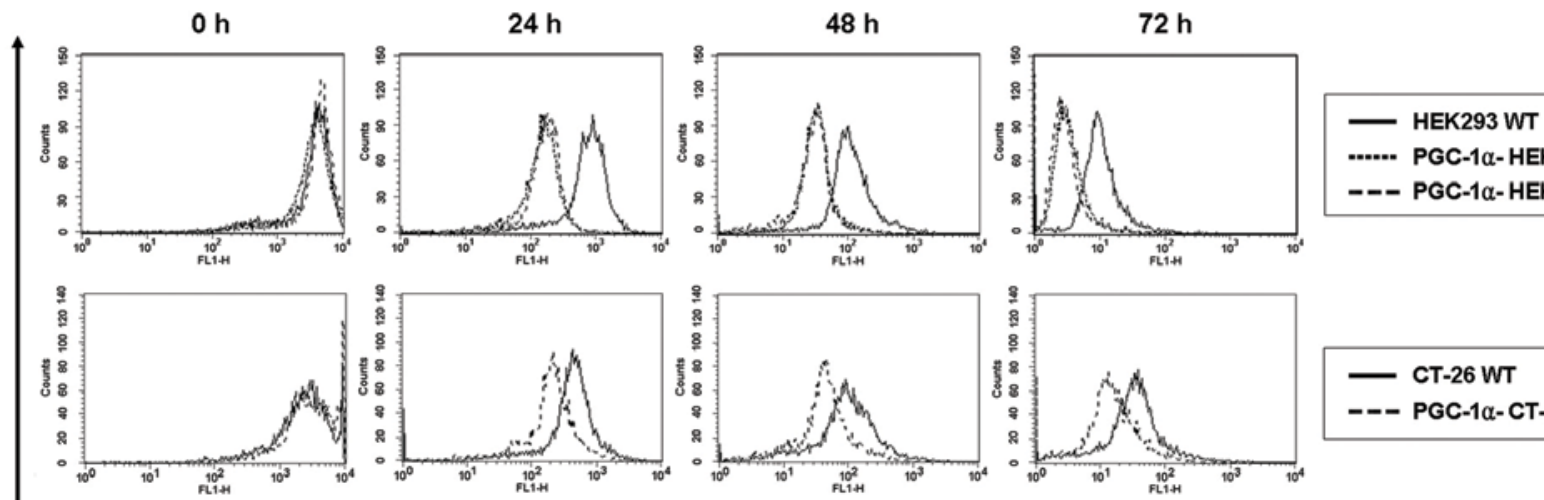

...... PGC-1 $\alpha$ - HEK293 \#1

- - - PGC-1 $\alpha$ - HEK293 \#3
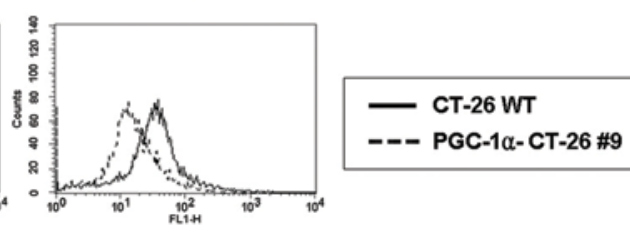

CFSE

Figure 1. Overexpression of PGC-1 $\alpha$ can enhance cell proliferation and cell viability. (A) PGC-1 $\alpha$ expression was assessed using western blotting with anti-PGC-1 $\alpha$ and anti-FLAG antibodies. $\beta$-actin was probed for equal protein loading. Densitometry results are expressed as mean \pm SD above the bands. (B) Immunofluorescence was performed using anti-FLAG antibody (green). Nuclei were stained with PI. The image is representative of 3 separate experiments. (C and D) PGC-1 $\alpha$ - or empty vector-transfected cells were seeded and cultured for the indicated times and cell proliferation was determined by cell counting (C). The data represent the mean \pm SD of 3 independent experiments. ${ }^{* * * *} \mathrm{P}<0.001$, vs. wild-type cells. (D) CFSE staining. CFSE-labeled HEK293 or PGC-1 $\alpha$-HEK293 cells $\left(1 \times 10^{5}\right.$ cells/well) and CFSE-labeled CT-26 or PGC-1 $\alpha$-CT-26 cells $\left(1 \times 10^{5}\right.$ cells/well) were incubated with a fresh medium containing $10 \%$ FBS for indicated times. The samples were analyzed by flow cytometry using a FACScan flow cytometer. Data analysis was done using CellQuest software (BD Biosciences). 
A

HT-29

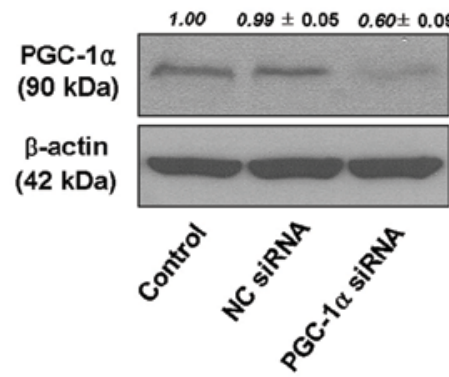

HT-29

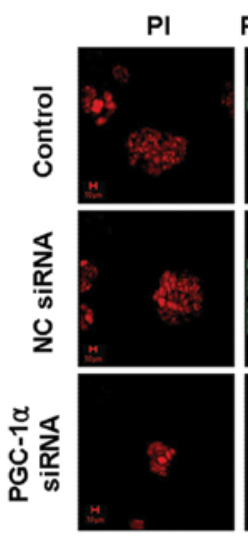

Merge
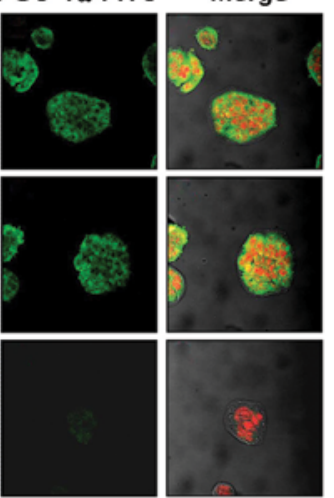
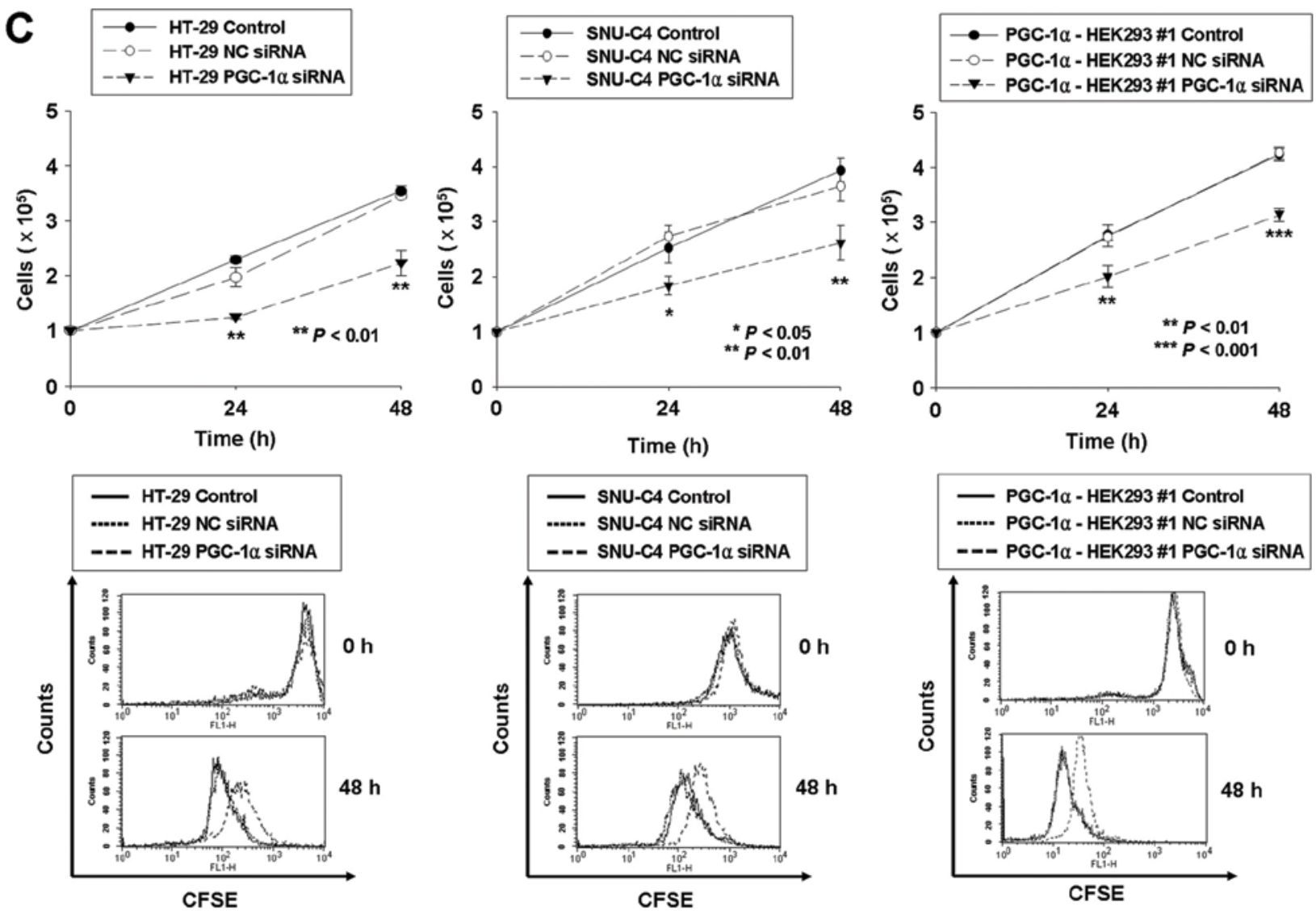

SNU-C4

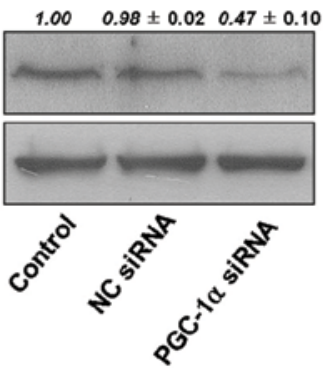

SNU-C4
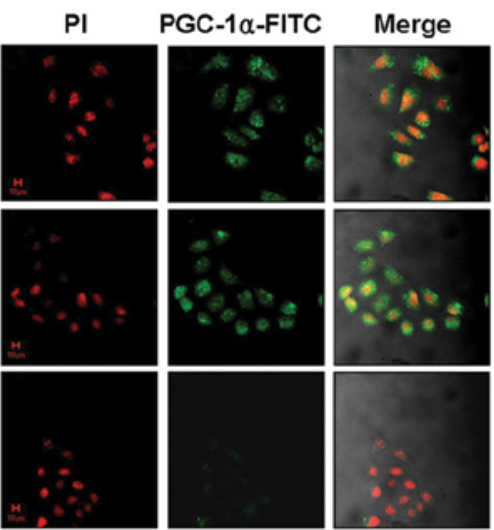
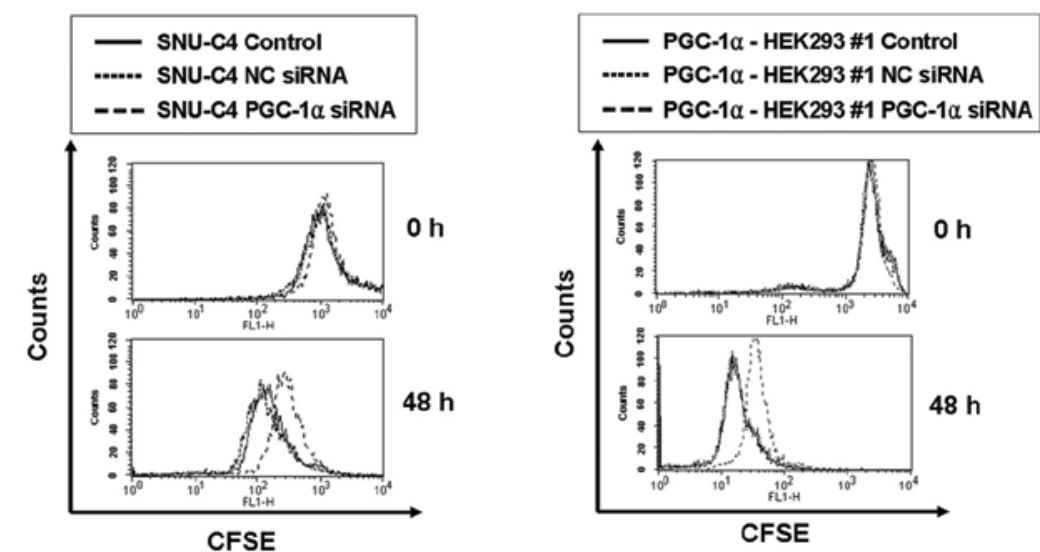

Figure 2. Knockdown of PGC-1 $\alpha$ expression results in decreased cell proliferation of HEK293 and human colorectal cancer cells. HT-29, SNU-C4, PGC-1 $\alpha$-HEK293 \#1 cells were transiently transfected by Lipofectamine with no siRNA (control), non-specific control (NC) siRNA, or siRNA for PGC-1 $\alpha$. (A) Protein lysates were prepared and subjected to western blot analysis as described in Materials and methods using corresponding antibodies. Equal protein loading was ensured by demonstrating uniform $\beta$-actin expression. The blots are representative of 5 separate experiments. Densitometry results are expressed as mean \pm SD above the bands. (B) Immunofluorescence staining was performed as described in Materials and methods using anti-PGC-1 $\alpha$ antibody (green). PI was used for nuclear staining. The image is representative of 5 separate experiments. (C) The transfected cells were seeded and cultured for indicated times and cell proliferation was determined by cell counting (upper panel) and CFSE staining (lower panel). The data represent the mean \pm SD of 5 independent experiments. ${ }^{*} \mathrm{P}<0.05,{ }^{* *} \mathrm{P}<0.01,{ }^{* * * *} \mathrm{P}<0.001$, vs. wild-type or NC siRNA cells. 
A
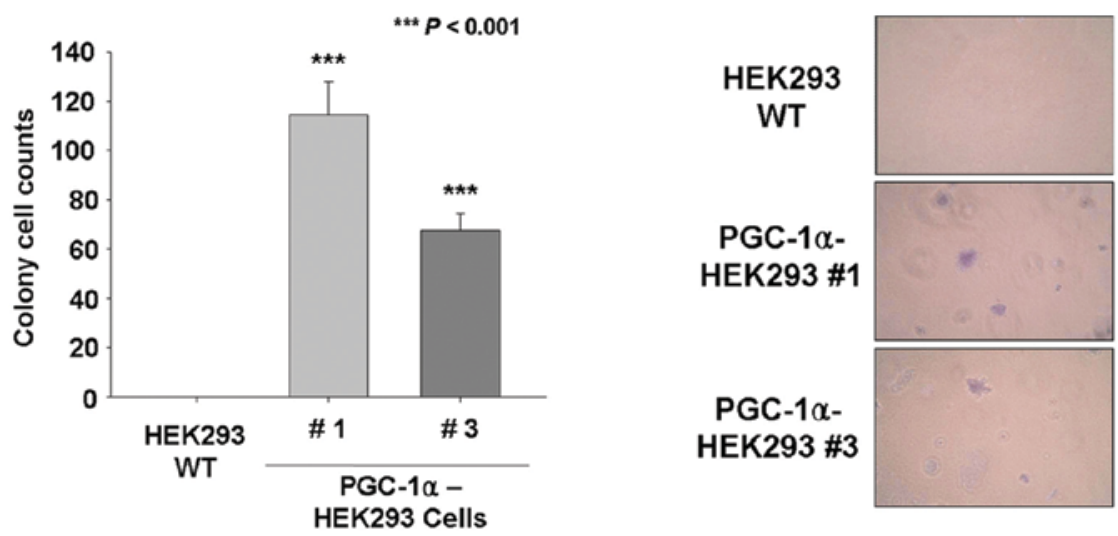

B

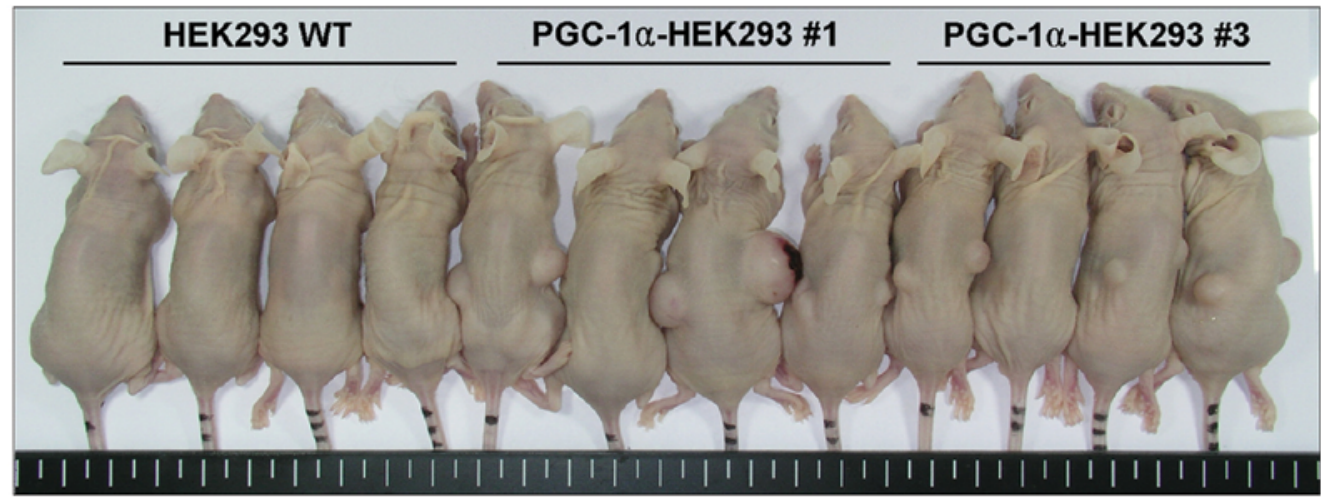

C

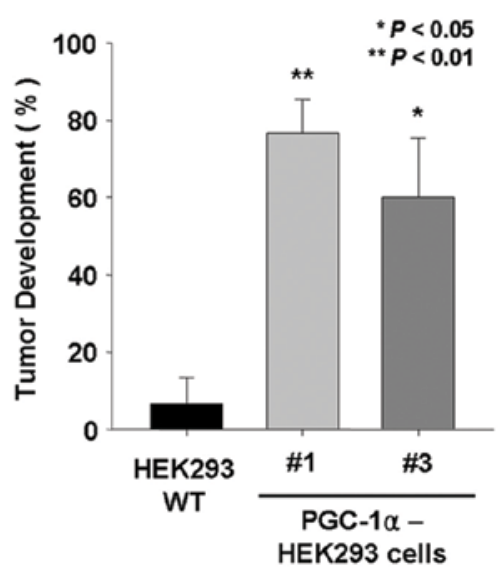

D
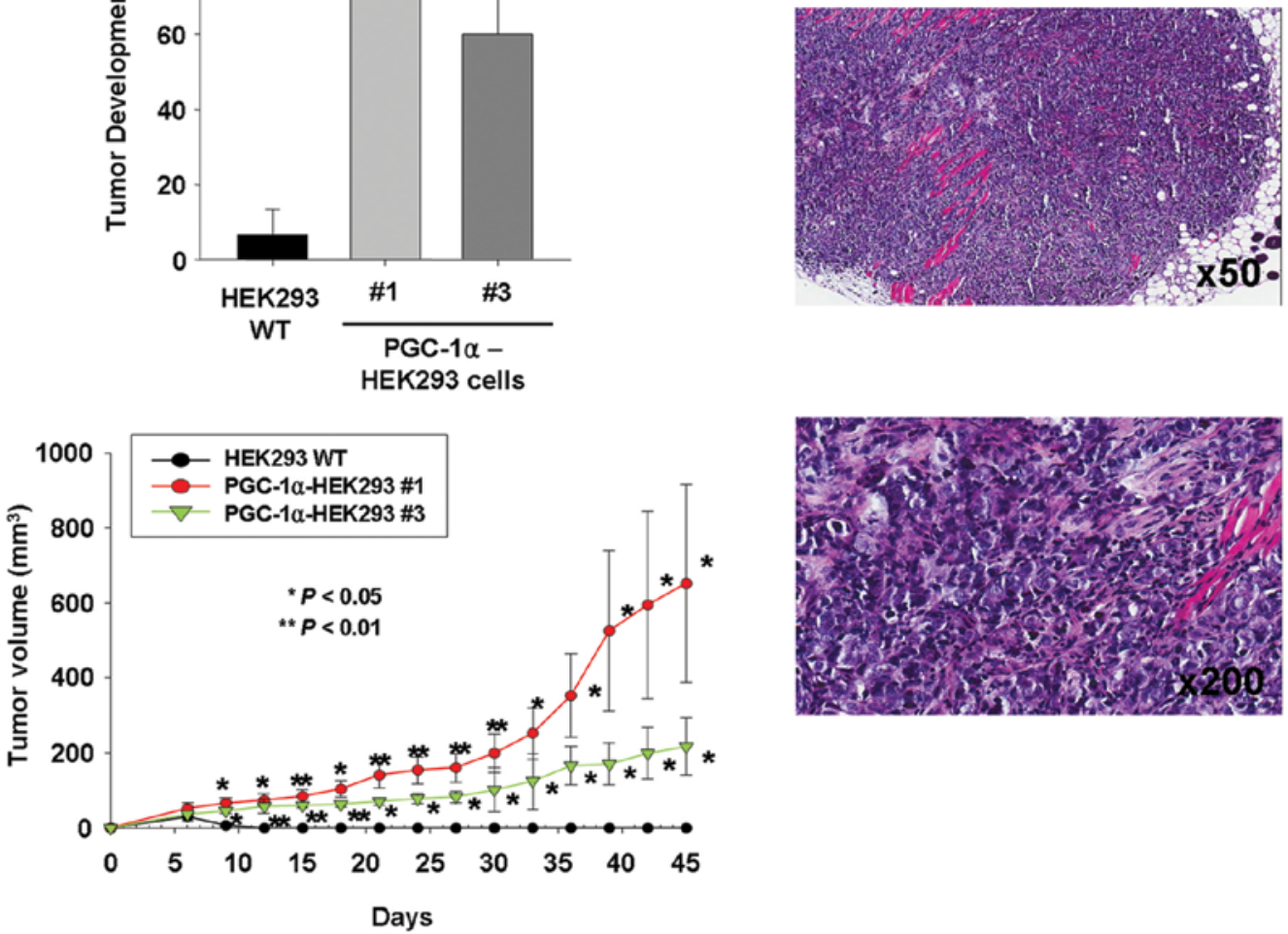

Figure 3. PGC-1 $\alpha$ promotes the oncogenic potential of HEK293 cells. (A) Colony-forming assay of wild-type and PGC-1 $\alpha$-overexpressing HEK293 cell lines. Left panel, the data show the average colony cell counts and SD of three independent assays. ${ }^{* * *} \mathrm{P}<0.001$, compared with the average number of colonies of wild-type HEK293 cells. Right panel, the representative light microscopy images of colony-forming assay results (x100). (B) Tumor formation following subcutaneous inoculation with HEK293 cells overexpressing PGC-1 $\alpha$ or empty vector was observed. Representative images taken at the time of sacrifice are shown. (C) The percentage of tumor formation in mock control HEK293 cell-injected and PGC-1 $\alpha$-overexpressing HEK293 cell-injected nude mice, respectively (upper panel), and the volume of subcutaneously formed tumors (lower panel). Data from 15 mice in each group are presented as mean \pm SD ${ }^{*} \mathrm{P}<0.05,{ }^{* *} \mathrm{P}<0.01$, vs. control HEK293 cells. (D) Hematoxylin and eosin staining. Stained sections were examined and photographed with Scanscope (Apero Technologies, Inc.). 
A
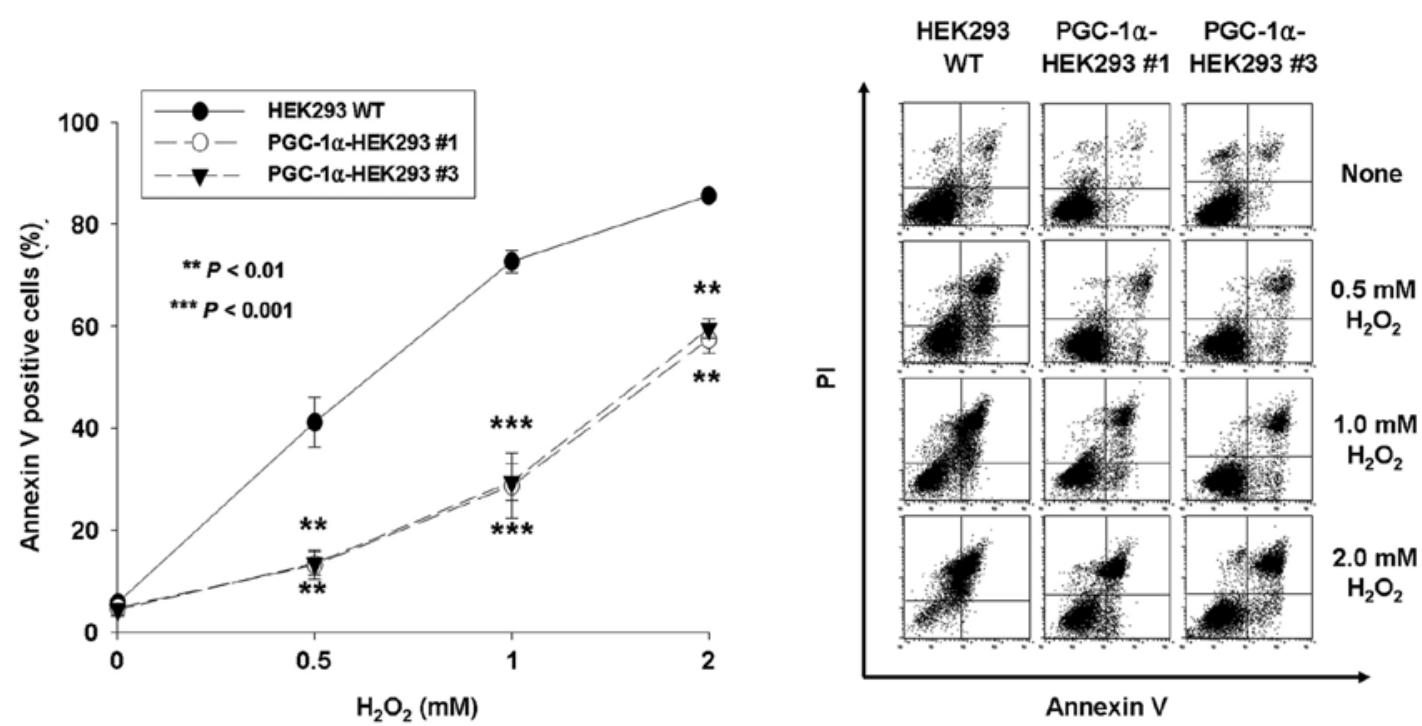

B

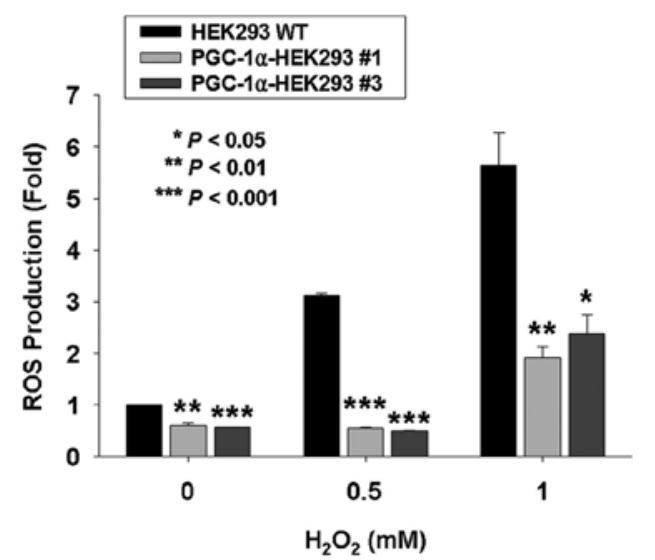

C
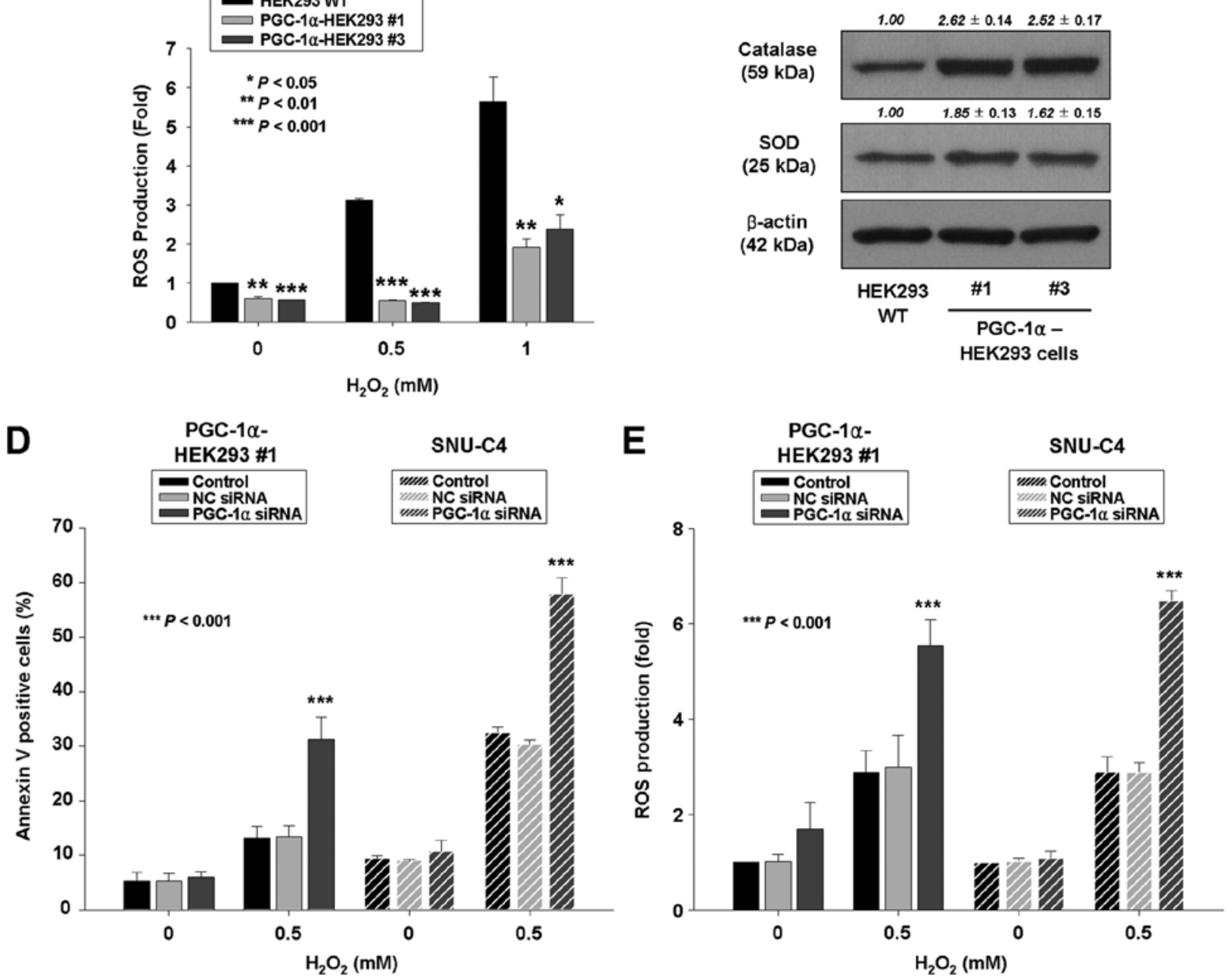

Figure 4. PGC-1 $\alpha$ protects HEK293 cells against oxidative stress. (A and B) Stable HEK293 cell lines expressing empty vector or PGC-1 $\alpha$ were seeded $24 \mathrm{~h}$ before treatment with various concentrations of $\mathrm{H}_{2} \mathrm{O}_{2}(0,0.5,1$ or $2 \mathrm{mmol} / \mathrm{l})$ for $24 \mathrm{~h}$. (A) Left panel, the percentage of apoptotic cells was determined by Annexin V-FITC/PI staining as described in Materials and methods. The data represent the mean \pm SD of three independent experiments. ${ }^{* *} \mathrm{P}<0.01,{ }^{* * * *} \mathrm{P}<0.001$, vs. wild-type HEK293 cells. Right panel, representative flow cytometric data. (B) After treatment, cells were labeled with an oxidative-sensitive dye (carboxy$\mathrm{H}_{2}$ DCFDA) and ROS levels were quantified by flow cytometry. ROS production was expressed as fold compared with wild-type HEK293 cells. The data represent the mean \pm SD of three independent experiments. ${ }^{*} \mathrm{P}<0.05,{ }^{* * *} \mathrm{P}<0.01,{ }^{* * * *} \mathrm{P}<0.001$, vs. wild-type HEK293 cells. (C) Western blotting of catalase and SOD in HEK293, PGC-1 $\alpha$-HEK293 \#1, and \#3 cells. Densitometry results are expressed as mean \pm SD above the bands. (D and E) PGC-1 $\alpha$-HEK293 \#1 and SNU-C4 cells were transiently transfected by Lipofectamine with no siRNA, non-specific control (NC) siRNA or PGC-1 $\alpha$ siRNA. (D) After transfection, cells were treated with $0.5 \mathrm{mM} \mathrm{H}_{2} \mathrm{O}_{2}$ for $24 \mathrm{~h}$. The percentage of apoptotic cells was determined by Annexin V-FITC/PI staining as described in Materials and methods. (E) In separate experiments, cells were treated with $0.5 \mathrm{mM} \mathrm{H}_{2} \mathrm{O}_{2}$ for $24 \mathrm{~h}$, after which they were labeled with an oxidative-sensitive dye (carboxy$\mathrm{H}_{2}$ DCFDA), and ROS levels were quantified by flow cytometry. The data represent the mean \pm SD of three independent experiments. ${ }^{* * * *} \mathrm{P}<0.001$, vs. control or NC siRNA cells. 


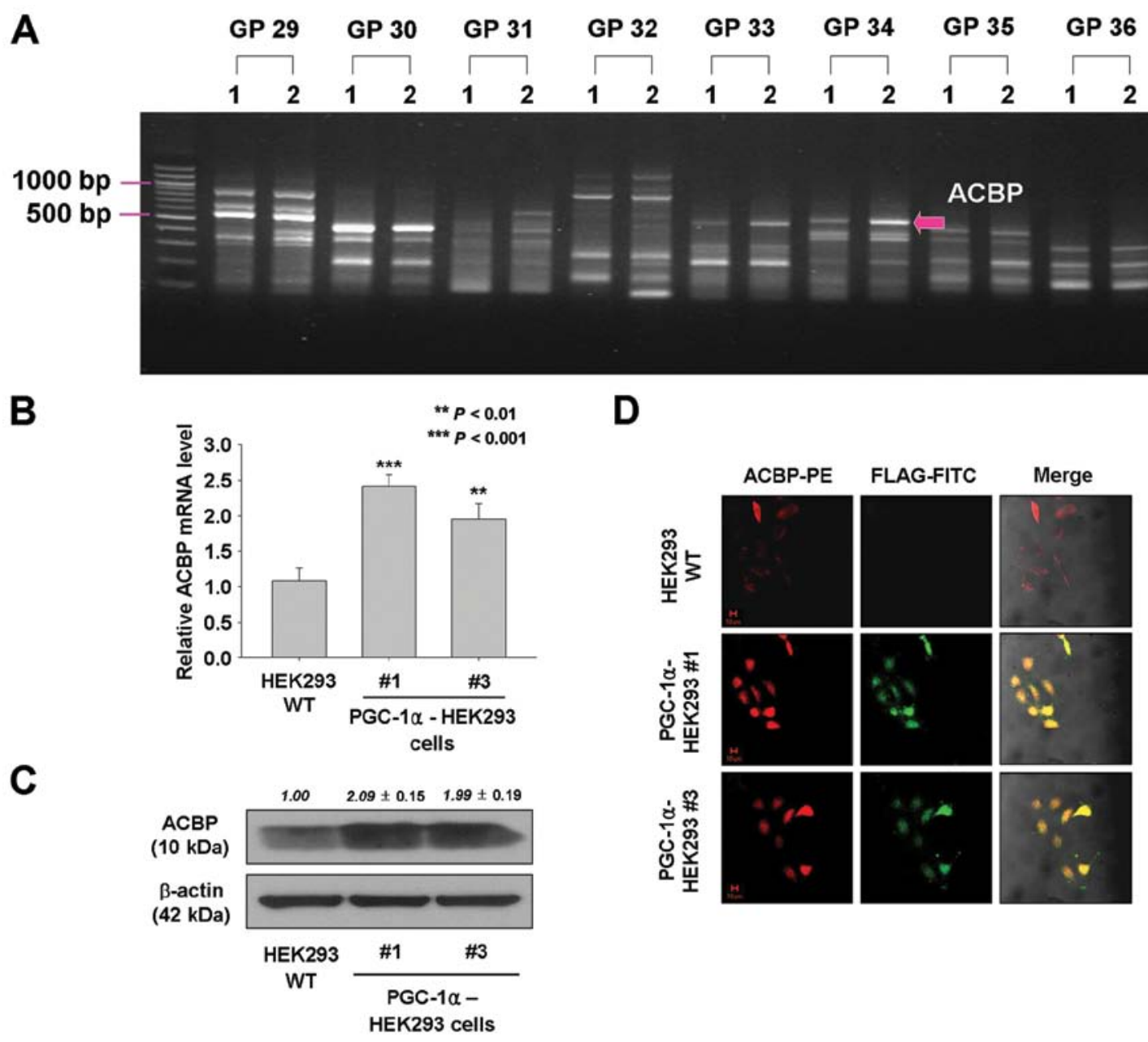

Figure 5. Upregulation of ACBP in stable HEK293 cell lines overexpressing PGC-1 $\alpha$. (A) Total RNA from PGC-1 $\alpha$ - or empty vector-expressing HEK293 cells was used for ACP-based GeneFishing analysis as described in Materials and methods. The amplicon bands showing different intensities between two cell lines were re-amplified and sequenced for gene annotation. Arrow indicates DEG bands that were identified as ACBP. (B) Relative mRNA levels of ACBP in wild-type HEK293 and PGC-1 $\alpha$-HEK293 cells (PGC-1 $\alpha$-HEK293 \#1 and PGC-1 $\alpha$-HEK293 \#3). The mRNA levels were determined using real-time RT-PCR. ACBP mRNA levels were normalized to GAPDH expression. Amplification was performed in triplicate, and SD is depicted as an error bar. "* $\mathrm{P}<0.01$, ${ }^{* * * *} \mathrm{P}<0.001$, vs. wild-type cells. (C) Protein levels of ACBP in wild-type HEK293, PGC-1 $\alpha$-HEK293 \#1, and \#3 cells. Protein lysates were prepared and subjected to western blot analysis as described in Materials and methods using an antibody against ACBP. Equal protein loading was ensured by showing uniform $\beta$-actin expression. The blot is representative of 3 separate experiments (left). Densitometry results are expressed as mean $\pm \mathrm{SD}\left({ }^{* * *} \mathrm{P}<0.001 \mathrm{vs}\right.$. wildtype cells) (right). (D) Immunofluorescence staining was performed as described in Materials and methods using anti-ACBP (red) and anti-FLAG (green) antibodies. GP, arbitrary general primer. 1, wild-type HEK293 cells; 2, PGC-1 $\alpha$-HEK293 \#1 cells; WT, wild-type.

HEK293 cells died after exposure to $1 \mathrm{mM} \mathrm{H}_{2} \mathrm{O}_{2}$, but only 28.7 and $29.4 \%$ of the PGC-1 $\alpha$-transfected HEK293 cells (PGC-1 $\alpha$-HEK293 \#1 and PGC-1 $\alpha$-HEK293 \#3) died, respectively (Fig. 4A). Consistent with these changes, wild-type HEK293 cells had significantly higher intracellular levels of ROS than PGC-1 $\alpha$-transfected HEK293 cells did $(5.64 \pm 0.55$ vs. $1.91 \pm 0.22$ - and $2.38 \pm 0.30$-fold, $\mathrm{P}<0.01$ and $\mathrm{P}<0.05$, respectively), as indicated by increased fluorescence in the presence of the compound DCF-DA (Fig. 4B).

In addition, the basal level of ROS was determined in wild-type, PGC-1 $\alpha$-HEK293 \#1 and PGC-1 $\alpha$-HEK293 \#3 cells. The basal level of ROS was reduced in PGC-1 $\alpha$-transfected cells compared with wild-type HEK293 cells $(0.60 \pm 0.03$ - and $0.57 \pm 0.01$-fold vs. 1 , respectively) (Fig. 4B). The reduced basal ROS of PGC-1 $\alpha$-HEK293 cells may be related to the increased expression of antioxidants. The expression of catalase was significantly 2.62- and 2.52-fold increased in PGC- $1 \alpha$ transfected HEK293 (PGC-1 $\alpha$-HEK293 \#1 and \#3) cells, respectively (Fig. 4C). The expression of SOD was significantly 1.85- and 1.62-fold increased in PGC-1 $\alpha$-transfected HEK293 (PGC-1 $\alpha$-HEK293 \#1 and \#3) cells, respectively (Fig. 4C). To confirm these results, the extent of $\mathrm{H}_{2} \mathrm{O}_{2}$-induced apoptosis and ROS level were measured in PGC-1 $\alpha$-siRNA- or non-specific control siRNA-transfected PGC-1 $\alpha$-HEK293 \#1 and SNU-C4 cells. The extent of $\mathrm{H}_{2} \mathrm{O}_{2}$-induced apoptosis and ROS level were significantly increased in PGC- $1 \alpha$-siRNA-transfected PGC-1 $\alpha$-HEK293 \#1 and SNU-C4 cells (Fig. 4D and E). The increased basal ROS of PGC-1 $\alpha$-siRNA-transfected PGC-1 $\alpha$-HEK293 \#1 and SNU-C4 cells may be caused by the decreased expression of antioxidants. Expression of SOD and catalase was decreased in PGC- $1 \alpha$-siRNA-transfected PGC-1 $\alpha$-HEK293 \#1 and SNU-C4 cells (Fig. 6A). These results indicate that PGC-1 $\alpha$ can protect HEK293 cells from oxidative stress such as that caused by $\mathrm{H}_{2} \mathrm{O}_{2}$. Decreased susceptibility to ROS-induced apoptosis may contribute to increased cell proliferation in PGC-1 $\alpha$-HEK293 cells. 
A

B

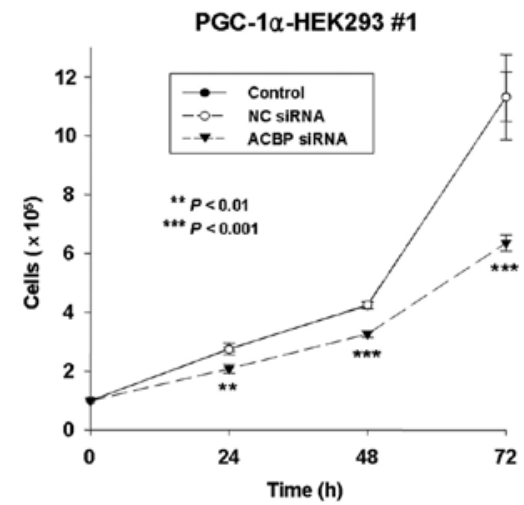

\section{-..... Control}

..... NC SIRNA

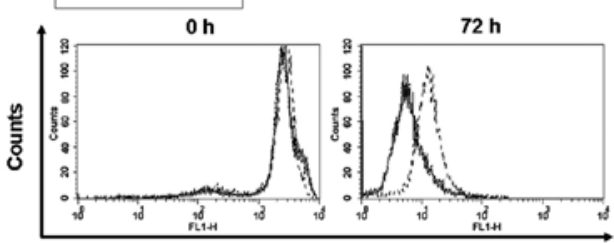

CFSE

\section{c}
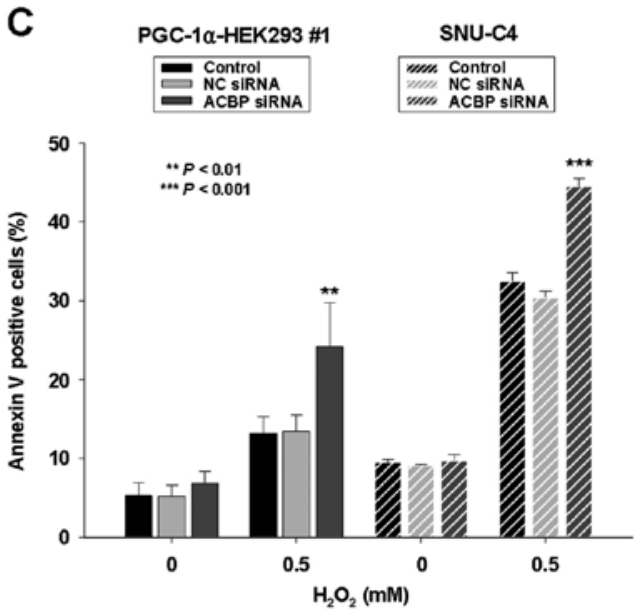

SNU-C4

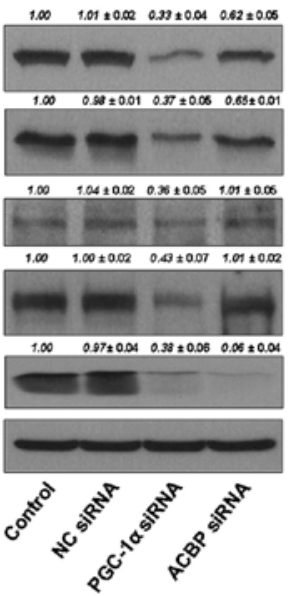

SNU-C4
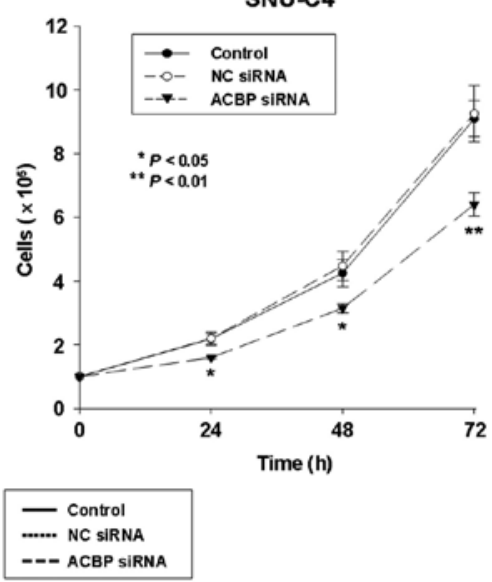

oh

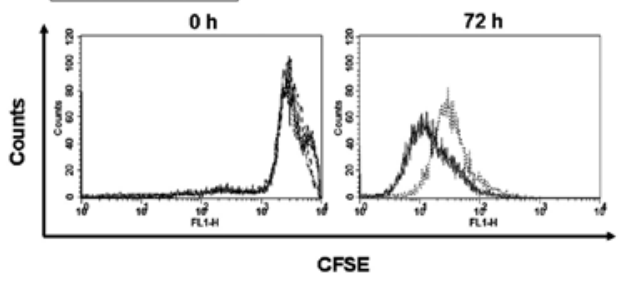

CFSE

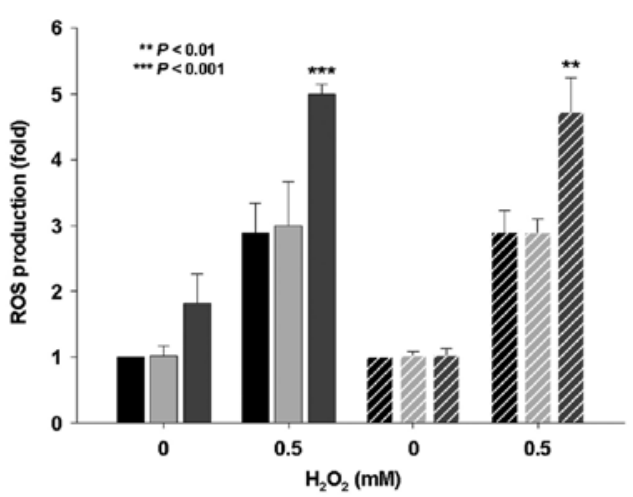

Figure 6. Downregulation of ACBP leads to decreased cell proliferation, decreased expression of catalase and SOD, and increased sensitivity to $\mathrm{H}_{2} \mathrm{O}_{2}$-induced apoptosis. PGC-1 $\alpha$-HEK293 \#1 and SNU-C4 cells were transiently transfected by Lipofectamine with no siRNA (control), non-specific control (NC) siRNA, siRNA for PGC-1 $\alpha$ or siRNA for ACBP. (A) Protein lysates were prepared and subjected to western blot analysis as described in Materials and methods using corresponding antibodies. Equal protein loading was ensured by demonstrating uniform $\beta$-actin expression. The blot is representative of 3 separate experiments. Densitometry results are expressed as mean \pm SD above the bands. (B) Upper panel, the transfected cells were seeded and cultured for indicated times. After that, cell proliferation was determined by cell counting. The data represent the mean $\pm \mathrm{SD}$ of 3 independent experiments. ${ }^{*} \mathrm{P}<0.05,{ }^{* *} \mathrm{P}<0.01,{ }^{* * *} \mathrm{P}<0.001$, vs. control or NC siRNA-transfected cells. Lower panel, CFSE analysis. (C) Left panel, after transfection, cells were treated with $0.5 \mathrm{mM} \mathrm{H}_{2} \mathrm{O}_{2}$ for $24 \mathrm{~h}$. The percentage of apoptotic cells was determined by Annexin V-FITC/PI staining as described in Materials and methods. Right panel, in separate experiments, cells were treated with $0.5 \mathrm{mM} \mathrm{H}_{2} \mathrm{O}_{2}$ for $24 \mathrm{~h}$, after which they were labeled with a carboxy- $\mathrm{H}_{2}$ DCFDA and ROS levels were quantified by flow cytometry. The data represent the mean $\pm \mathrm{SD}$ of three independent experiments. ${ }^{*} \mathrm{P}<0.05,{ }^{* *} \mathrm{P}<0.01,{ }^{* * *} \mathrm{P}<0.001$, vs. control or NC siRNA-transfected cells. 
Overexpression of $P G C$-1 $\alpha$ may lead to upregulation of acylCoA binding protein (ACBP) in HEK293 cells. To investigate genes that contribute to PGC-1 $\alpha$-induced cell proliferation and tumorigenesis, ACP-based GeneFishing PCR was performed, and the band intensities between PGC- $1 \alpha$-transfected HEK293 cells and empty vector-expressing HEK293 cells were compared. By densitometric analysis of amplified cDNA fragments, one fragment showing $>2$-fold different intensities between two cell lines was observed (Fig. 5A). The amplicon band was eluted from agarose gel, re-amplified, and sequenced, and the sequences were used in a BLAST search to identify their gene annotations. BLAST analysis identified the ACBP.

To confirm the upregulated expression of ACBP in PGC-1 $\alpha$ overexpressing HEK293 cells, real-time RT-PCR, immunoblot analysis, and immunofluorescence staining were performed. As shown in Fig. 5B and C, mRNA and protein levels of ACBP were approximately 2.4- and 2-fold (mRNA) and 2.09- and 1.99 -fold (protein) higher in PGC-1 $\alpha$-HEK293 \#1 and \#3 cells, respectively, than in wild-type HEK 293 cells. In addition, immunofluorescence staining showed that expression levels of ACBP were increased in PGC-1 $\alpha$-overexpressing HEK293 cells and that most of the ACBP was co-localized with PGC-1 $\alpha$ (Fig. 5D). Furthermore, the expression of ACBP was decreased in PGC- $1 \alpha$ siRNA-transfected PGC-1 $\alpha$-HEK293 \#1 cells based on western blot results (Fig. 6A). However, the expression of PGC-1 $\alpha$ was not affected by ACBP siRNA knockdown (Fig. 6A). Thus, these data indicate that the expression of ACBP may be regulated by the activity of PGC- $1 \alpha$.

Downregulation of ACBP leads to decreased cell proliferation and increased sensitivity to $\mathrm{H}_{2} \mathrm{O}_{2}$-induced apoptosis. The above-described findings indicated that ACBP expression was regulated by PGC- $1 \alpha$. To examine the involvement of ACBP in regulating cell proliferation by PGC-1 $\alpha$ expression, ACBP was downregulated in an ACBP siRNA knockdown experiment in PGC-1 $\alpha$-transfected HEK293 cells and SNU-C4 cells. In PGC-1 $\alpha$-transfected HEK293 and SNU-C4 cells, the endogenous expression of ACBP was substantially reduced following transfection with siRNA for ACBP (Fig. 6A); whereas, the proliferation of ACBP siRNA-transfected PGC-1 $\alpha$-HEK293 \#1 and SNU-C4 cells were significantly inhibited compared to control PGC-1 $\alpha$-HEK293 \#1 and SNU-C4 cells (Fig. 6B; 44 and 30\% reductions, respectively). However, protein levels of PGC-1 $\alpha$ were not downregulated in ACBP siRNA-transfected PGC-1 $\alpha$-HEK293 \#1 and SNU-C4 cells (Fig. 6A).

In addition, to evaluate the role of ACBP in the regulation of sensitivity to $\mathrm{H}_{2} \mathrm{O}_{2}$-induced apoptosis, the extent of $\mathrm{H}_{2} \mathrm{O}_{2}$-induced apoptosis and ROS level were measured in ACBP siRNA-transfected or non-silencing siRNA-transfected PGC-1 $\alpha$-HEK293 \#1 and SNU-C4 cells. The extent of $\mathrm{H}_{2} \mathrm{O}_{2-}$ induced apoptosis and ROS level were significantly increased in ACBP siRNA-transfected PGC-1 $\alpha$-HEK293 \#1 and SNU-C4 cells compared to control PGC-1 $\alpha$-HEK293 \#1 and SNU-C4 cells (Fig. 6C). Expression of SOD and catalase was decreased by ACBP siRNA knockdown in PGC-1 $\alpha$-HEK293 and SNU-C4 cells (Fig. 6A). These results indicate that ACBP can protect PGC-1 $\alpha$-HEK293 \#1 and SNU-C4 cells from oxidative stress such as that mediated by $\mathrm{H}_{2} \mathrm{O}_{2}$. Increased susceptibility to ROS-induced apoptosis may contribute to

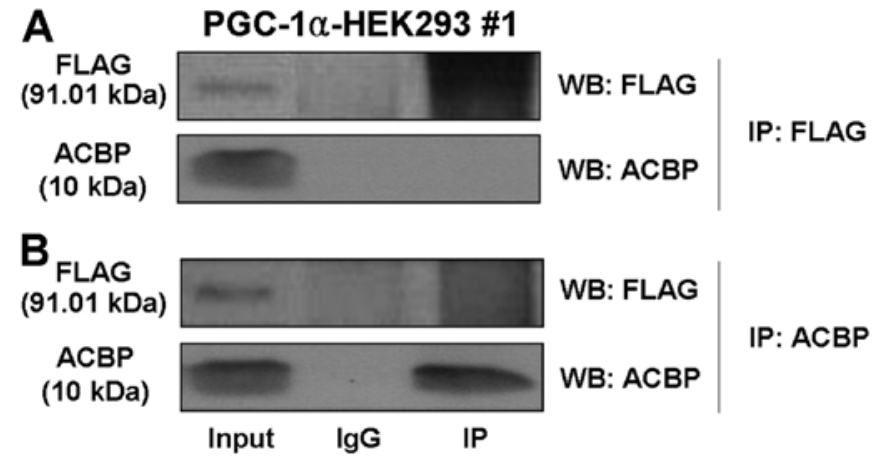

Figure 7. PGC-1 $\alpha$ does not directly interact with ACBP. Co-immunoprecipitation with FLAG (A) and ACBP (B) was performed using cell extracts prepared from PGC-1 $\alpha$-HEK293 \#1 cells. Immunoprecipitates were immunoblotted with anti-FLAG and anti-ACBP antibodies. Co-immunoprecipitation with normal IgG was used as control.

decreased cell proliferation by ACBP siRNA knockdown in PGC-1 $\alpha$-HEK293 \#1 and SNU-C4 cells. The decreased cell proliferation and increased sensitivity to $\mathrm{H}_{2} \mathrm{O}_{2}$-induced apoptosis by ACBP knockdown is similar to that observed in PGC- $1 \alpha$ siRNA-transfected PGC-1 $\alpha$-HEK293 \#1 and SNU-C4 cells. Thus, these results suggest that PGC-1 $\alpha$ knockdown downregulates cell proliferation and increases $\mathrm{H}_{2} \mathrm{O}_{2}$-induced apoptosis of HEK293 and SNU-C4 cells through downregulation of ACBP.

$P G C-1 \alpha$ does not physically interact with ACBP. The above results suggested that PGC-1 $\alpha$ expression influences ACBP expression, but interactions between PGC- $1 \alpha$ and ACBP have not previously been described. Thus, we tested the possibility that PGC- $1 \alpha$ can interact with ACBP. Using antibodies against FLAG, we found that FLAG antibody did not immunoprecipitate ACBP (Fig. 7A). Consistent with this outcome, ACBP antibodies did not immunoprecipitate FLAG-PGC-1 $\alpha$ (Fig. 7B). These results indicate that PGC-1 $\alpha$ did not directly interact with ACBP.

Increased Sp1 expression may contribute to increased ACBP expression by $P G C-1 \alpha$. The results described above showed that ACBP is a target of PGC-1 $\alpha$; however, the mechanisms for its regulation by PGC- $1 \alpha$ are not clear. A previous report suggests that the promoter of ACBP has an Sp1 binding site (27). Thus, we investigated whether PGC-1 $\alpha$ expression can influence the expression of Sp1. The results indicated that the expression of Sp1 was significantly 3 -fold increased in PGC-1 $\alpha$-HEK293 \#1 and \#3 cells compared to wild-type HEK293 cells (Fig. 8A). In addition, PGC-1 $\alpha$ siRNA transfection led to reduced expression of Sp1 in PGC-1 $\alpha$-HEK293 \#1 and SNU-C4 cells (Fig. 6A).

The knockdown of Sp1 in PGC-1 $\alpha$-HEK293 \#1 and SNU-C4 was confirmed by western blot analysis. The expression of Sp1 was decreased in PGC-1 $\alpha$-HEK293\#1 and SNU-C4 cells (Fig. 8B). Knockdown of Sp1 resulted in decreased cell proliferation, decreased expression of ACBP, decreased expression of catalase and SOD, increased ROS production, and increased $\mathrm{H}_{2} \mathrm{O}_{2}$-induced apoptosis in PGC- $\alpha$-HEK293 \#1 and SNU-C4 cells (Fig. 8B-D), which is similar to those 
A

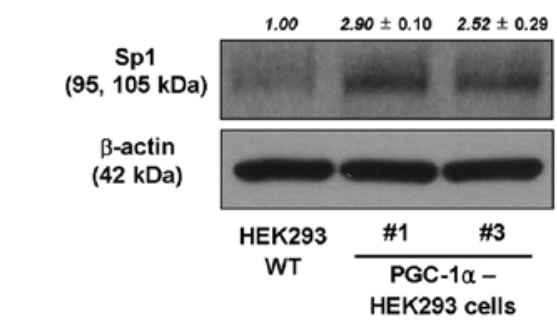

C

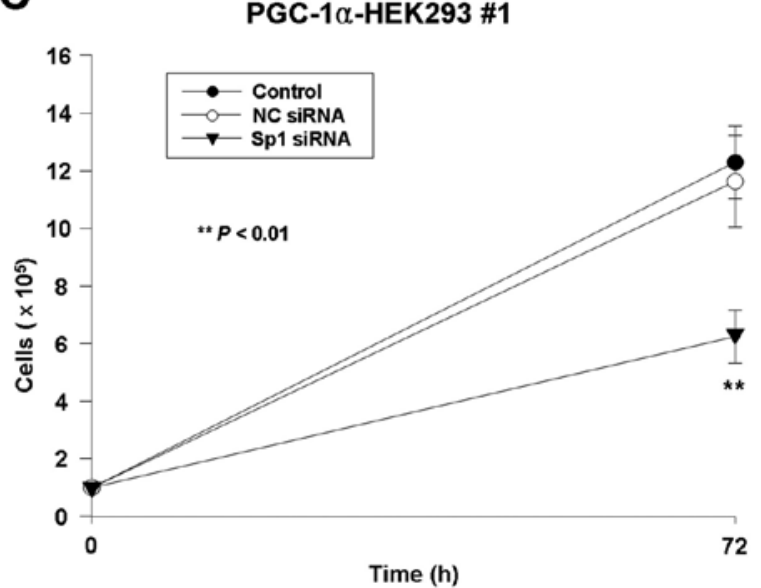

D
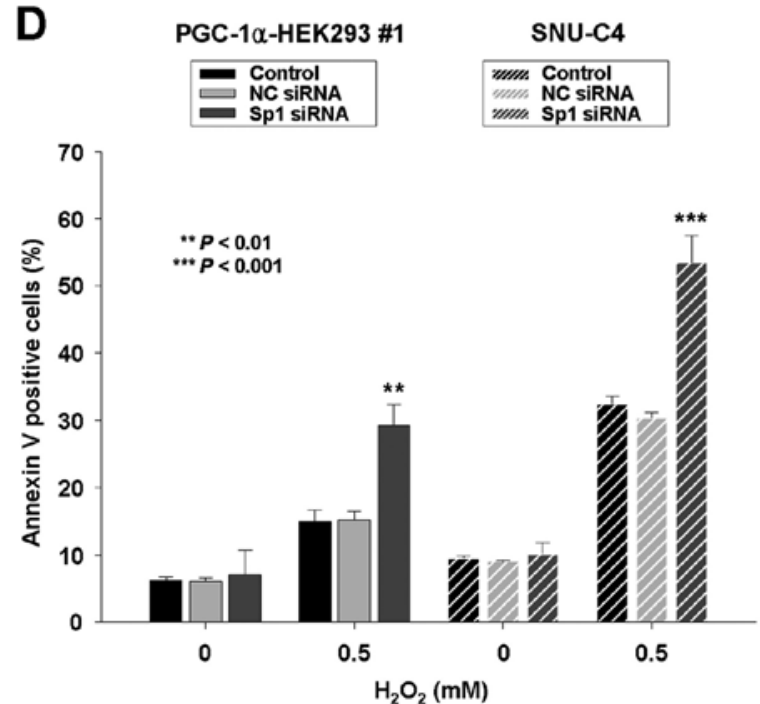

B

$\mathrm{Sp} 1$
$(95,105 \mathrm{kDa})$

Catalase
(59 kDa)

PGC-1 $\alpha$

ACBP

(10 kDa)

$\beta$-actin

(42 kDa)

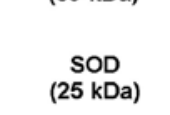
(91.01, $90 \mathrm{kDa})$

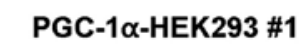

$1.00 \quad 0.99 \pm 0.03 \quad 0.35 \pm 0.00$
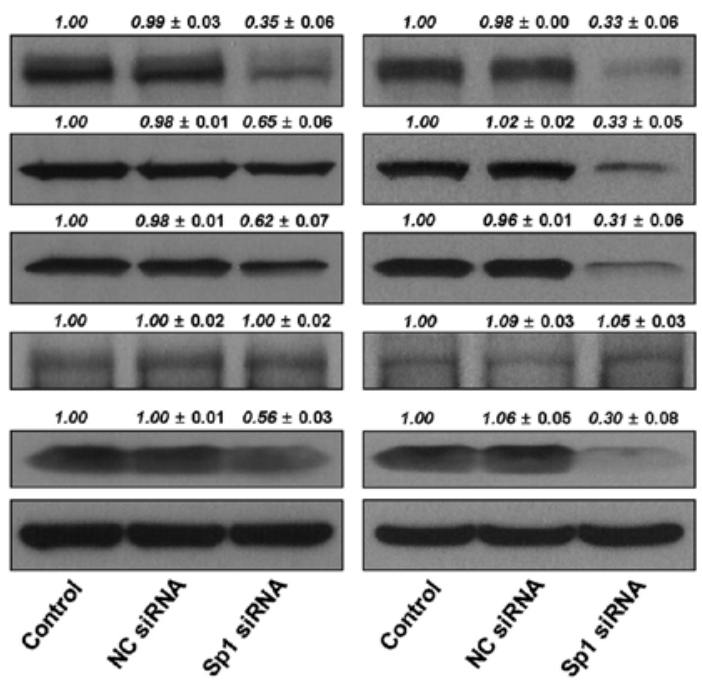

SNU-C4

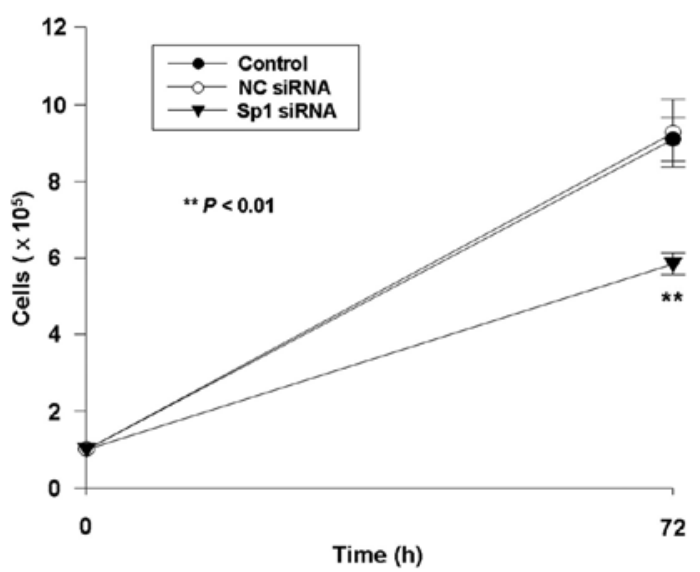

PGC-1 $\alpha$-HEK293 \#1

SNU-C4

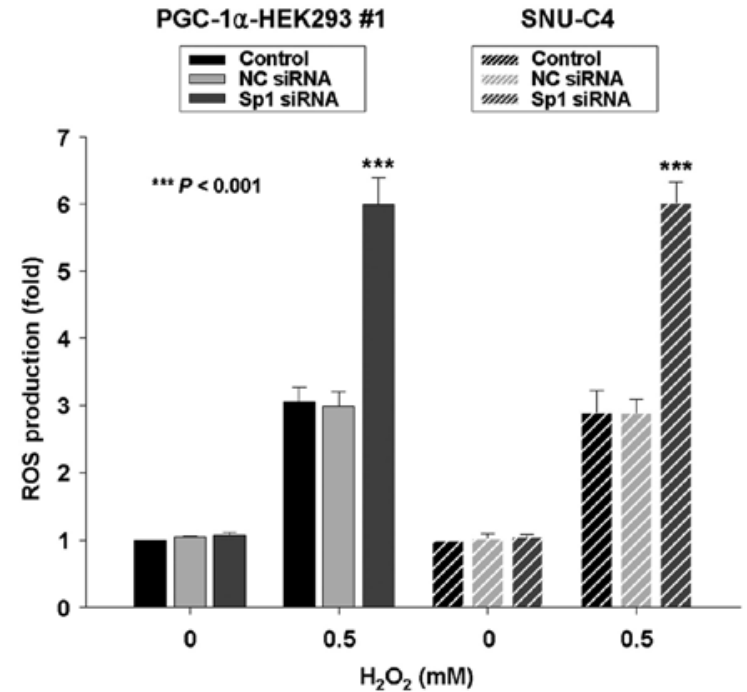

Figure 8. Increased Sp1 expression may contribute to increased ACBP expression by PGC-1 $\alpha$. (A) Protein levels of Sp1 in wild-type HEK293 and PGC-1 $\alpha$-HEK293 cells (PGC-1 $\alpha$-HEK293 \#1 and PGC-1 $\alpha$-HEK293 \#3). $\beta$-actin was probed for equal protein loading. Densitometry results are expressed as mean \pm SD above the bands. (B) PGC-1 $\alpha$-HEK293 \#1 and SNU-C4 cells were transiently transfected by Lipofectamine with no siRNA (control), NC siRNA, or $\mathrm{Sp} 1$ siRNA. Protein lysates were prepared and subjected to western blot analysis as described in Materials and methods using corresponding antibodies. Equal protein loading was ensured by demonstrating uniform $\beta$-actin expression. The blot is representative of 3 separate experiments. Densitometry results are expressed as mean \pm SD above the bands. (C and D) PGC-1 $\alpha$-HEK293 \#1 and SNU-C4 cells were transiently transfected by Lipofectamine with no siRNA (control), NC siRNA, or Sp1 siRNA. (C) The transfected cells were seeded and cultured for $72 \mathrm{~h}$. The cell proliferation was determined by cell counting. The data represent the mean \pm SD of 3 independent experiments. ${ }^{* *} \mathrm{P}<0.01$, vs. control or NC siRNA-transfected cells. (D) Left panel, after transfection, cells were treated with $0.5 \mathrm{mM} \mathrm{H}_{2} \mathrm{O}_{2}$ for $24 \mathrm{~h}$. The percentage of apoptotic cells was determined by Annexin V-FITC/PI staining as described in Materials and methods. Right panel, in separate experiments, cells were treated with $0.5 \mathrm{mM} \mathrm{H}_{2} \mathrm{O}_{2}$ for $24 \mathrm{~h}$, after which they were labeled with a carboxy- $\mathrm{H}_{2}$ DCFDA, and ROS levels were quantified by flow cytometry. The data represent the mean $\pm \mathrm{SD}$ of three independent experiments. ${ }^{* *} \mathrm{P}<0.01,{ }^{* * *} \mathrm{P}<0.001$, vs. control or $\mathrm{NC}$ siRNA-transfected cells. 
observed in PGC-1 $\alpha$ siRNA-transfected PGC-1 $\alpha$-HEK293 \#1 cells. Taken together, these data suggest that the increased ACBP expression by PGC-1 $\alpha$ may be caused by increased Sp1 expression.

\section{Discussion}

In the present study, PGC-1 $\alpha$-overexpressing HEK293 and CT-26 cells were established, and PGC-1 $\alpha$ expression was confirmed by western blotting and immunofluorescence staining. Overexpression of PGC-1 $\alpha$ increased cell proliferation and greatly enhanced tumorigenesis in a colony-forming assay and a Balb/c immunodeficient mouse model, suggesting that PGC-1 $\alpha$ may be involved in the control of cell proliferation and tumorigenesis. In addition, downregulation of PGC-1 $\alpha$ led to decreased cell proliferation in HT-29, SNU-C4, and PGC-1 $\alpha$-HEK293 cells. However, the detailed molecular mechanisms for increased cell proliferation and tumorigenesis by PGC- $1 \alpha$ overexpression remain to be clarified, and the role of PGC-1 $\alpha$ in cancer has been controversial. Several studies support that PGC-1 $\alpha$ has antitumor activity because decreased PGC-1 $\alpha$ expression is related to cancer progression and poor prognosis in breast cancer (16-18). In addition, PGC-1 $\alpha$ overexpression induces apoptosis of ovarian cancer cells through the coordinated regulation of Bcl-2 and Bax expression (19). In contrast, several studies support that PGC-1 $\alpha$ has tumorpromoting activity. For example, PGC- $1 \alpha$ protects cells from apoptosis in neuroblastoma cells (20) and promotes cell growth in prostate cancer cells (21). Increased cell proliferation and tumorigenesis by PGC-1 $\alpha$ overexpression observed in this study is consistent with the findings that PGC-1 $\alpha$ promotes cell growth in prostate cancer cells and tumor growth $(21,28)$.

Previous studies have suggested that ROS have dual roles in cancer promotion (29) or cancer suppression $(30,31)$ in tumorigenesis. ROS generation is a necessary step during apoptosis because ROS scavengers block or delay apoptosis. PGC- $1 \alpha$ induces antioxidant enzymes such as SOD and catalase, resulting in reduced ROS levels in $\mathrm{H}_{2} \mathrm{O}_{2}$-treated neuronal cells $(10,20)$. In this study, to confirm whether the increased expression of PGC- $1 \alpha$ can protect cells from ROS-induced cell death, the levels of ROS and the extent of apoptosis during $\mathrm{H}_{2} \mathrm{O}_{2}$ treatment were assessed. We found that $\mathrm{H}_{2} \mathrm{O}_{2}$-induced ROS production and apoptosis were attenuated by PGC-1 $\alpha$ expression. In addition, the extent of $\mathrm{H}_{2} \mathrm{O}_{2}$-induced apoptosis and ROS level were increased in PGC-1 $\alpha$ siRNA-transfected PGC-1 $\alpha$-HEK293 and SNU-C4 cells. These results are similar to those showing that PGC- $1 \alpha$ can protect neuroblastoma cells from $\mathrm{H}_{2} \mathrm{O}_{2}$-mediated cell death (20). Thus, the current findings suggest that the decreased ROS-induced apoptosis might contribute to enhanced cell proliferation by PGC-1 $\alpha$.

To identify the molecular targets for PGC-1 $\alpha$, DEGs in control and PGC- $1 \alpha$-HEK293 cells were examined using the GeneFishing DEG screening system. ACBP was found to be upregulated in PGC-1 $\alpha$-overexpressing HEK293 cells. Furthermore, upregulated ACBP expression was confirmed by real-time RT-PCR, western blotting and immunofluorescence staining. In addition, PGC-1 $\alpha$ siRNA transfection led to downregulation of ACBP expression in PGC-1 $\alpha$-HEK293 and SNU-C4 cells. However, the expression of PGC-1 $\alpha$ was not downregulated by ACBP siRNA transfection. These data suggest that ACBP is a target of PGC- $1 \alpha$. This relationship between PGC-1 $\alpha$ and ACBP had not been reported previously. To confirm whether PGC- $1 \alpha$ enhances cell proliferation and tumorigenesis through upregulation of ACBP, we performed ACBP siRNA knockdown experiments in PGC-1 $\alpha$-HEK293 and SNU-C4 cells. ACBP knockdown resulted in decreased cell proliferation, increased $\mathrm{H}_{2} \mathrm{O}_{2}$-induced ROS production and apoptosis, and reduced expression of catalase and SOD, which is similar to outcomes for PGC-1 $\alpha$ siRNA-transfected PGC-1 $\alpha$-HEK 293 and SNU-C4 cells. Taken together, these data provide direct evidence that PGC-1 $\alpha$ enhances cell proliferation and tumorigenesis through upregulation of ACBP.

ACBP is reported to play a role in a number of important physiological and biochemical functions, such as regulation of glucose-induced insulin secretion from pancreatic $\beta$-cells $(32,33)$, stimulation of steroidogenesis through peripheral-type benzodiazepine receptor (PBR) (34-36), and modulation of cell proliferation (37). ACBP/DBI, originally described as a cytosolic protein and identified as stimulating the synthesis of pregnenolone in mitochondrial fractions, enhances steroidogenesis via PBRs. ACBP/DBI does so by promoting cholesterol delivery to the inner mitochondrial membrane (38), which represents the rate-determining step of steroid biosynthesis (39). Several lines of evidence indicate that this ligand, which binds at PBRs, may be involved in the regulation of cell growth and differentiation (40). In addition, serum cholesterol levels and ACBP/DBI are significantly increased in patients with hepatocellular carcinoma (41). ACBP is localized throughout the cytosol and at organelles such as the Golgi apparatus and endoplasmic reticulum (42) and the nucleus and the perinuclear area (43). This study showed that most of the ACBP was co-localized with PGC-1 $\alpha$. Thus, we also examined whether PGC-1 $\alpha$ directly interacts with ACBP by co-immunoprecipitation; however, PGC- $1 \alpha$ did not do so. We sought to identify the molecular mechanism for increased expression of ACBP by PGC-1 $\alpha$. Because a previous study suggested that the ACBP promoter has an Spl binding site (27), we focused on the role of Sp1 in the PGC-1 $\alpha$-ACBP axis, which may be involved in the regulation of cell proliferation, using Sp1 siRNA transfection. Increased expression of Sp1 might contribute to increased expression of ACBP by PGC- $1 \alpha$; however, we did not examine the effect of Sp1 on the promoter activity of ACBP in this study. We cannot exclude some role for SREBP-1c, PPAR $\alpha$, or PPAR $\gamma$ in regulating cell proliferation by PGC- $1 \alpha$ because we did not examine their expression, which has been reported to be involved in the regulation of ACBP. Further investigations to clarify the detailed mechanisms for Sp1-induced ACBP expression and increased Sp1 expression by PGC-1 $\alpha$ are needed.

Several groups have reported that $\mathrm{Sp} 1$ is overexpressed in a variety of cancers and is highly correlated with stage and poor prognosis of the cancers (44-46). In the present study, we observed an increased expression of Sp1 in PGC-1 $\alpha$-HEK 293 \#1 and \#3 cells. In addition, Sp1 siRNA transfection resulted in decreased cell proliferation, decreased ACBP expression, decreased expression of catalase and SOD, and increased $\mathrm{H}_{2} \mathrm{O}_{2}$-induced apoptosis, which are similar to those of PGC-1 $\alpha$ siRNA transfection in PGC-1 $\alpha$-HEK293 and SNU-C4 cells. Our data are consistent with previous reports that inhibiting or knocking down Sp1 to normal cellular 
levels usually decreases tumor formation, growth, and metastasis (47-49). Previous studies also suggest that catalase and SOD gene transcriptional regulation is highly dependent on Sp1 $(50,51)$. Even though we did not examine the promoter activity of catalase and SOD by Sp1, our data support that the decreased expression of Sp1 may contribute to reduced expression of catalase and SOD, increased $\mathrm{H}_{2} \mathrm{O}_{2}$-induced $\mathrm{ROS}$ production, and apoptosis. Taken together, we suggest hypothetical molecular mechanisms for increased cell proliferation and tumorigenesis by PGC-1 $\alpha$. In brief, the increased cell proliferation and tumorigenesis by PGC-1 $\alpha$ expression may be related to the upregulation of ACBP through increased Sp1 expression; the decreased cell proliferation by Sp1 or ACBP knockdown is similar to that achieved by PGC-1 $\alpha$ downregulation, and Sp1 or ACBP expression is downregulated in the PGC-1 $\alpha$ siRNA knockdown experiment.

In conclusion, the results of this study suggest that PGC-1 $\alpha$ overexpression upregulates proliferation of HEK293 cells through upregulation of ACBP by increased Sp1 expression. Moreover, PGC-1 $\alpha$ expression correlates with enhanced tumorigenesis. Further studies to clarify the molecular interactions between PGC-1 $\alpha$ and Sp1 are needed. The current findings also suggest that PGC-1 $\alpha$ may be a good candidate molecular target for cancer therapeutics because PGC- $1 \alpha$ expression is related to enhanced cell proliferation and tumorigenesis.

\section{Acknowledgements}

This study was supported by the National Research Foundation of Korea (NRF) Grant funded by the Korean Government (Ministry of Education, Science and Technology) (R13-2002044-05002-0) and by the Basic Science Research Program through the NRF funded by the Ministry of Education, Science and Technology (NRF-2011-355-E00017).

\section{References}

1. Puigserver $\mathrm{P}, \mathrm{Wu} \mathrm{ZD}$, Park $\mathrm{CW}$, Graves R, Wright $\mathrm{M}$ and Spiegelman BM: A cold-inducible coactivator of nuclear receptors linked to adaptive thermogenesis. Cell 92: 829-839, 1998.

2. Finck BN and Kelly DP: PGC-1 coactivators: inducible regulators of energy metabolism in health and disease. J Clin Invest 116: 615-622, 2006.

3. Handschin C and Spiegelman BM: Peroxisome proliferator-activated receptor $\gamma$ coactivator 1 coactivators, energy homeostasis, and metabolism. Endocr Rev 27: 728-735, 2006.

4. Wu Z, Puigserver P, Andersson U, Zhang C, Adelmant G Mootha V, Troy A, Cinti S, Lowell B, Scarpulla RC and Spiegelman BM: Mechanisms controlling mitochondrial biogenesis and respiration through the thermogenic coactivator PGC-1. Cell 98: 115-124, 1999.

5. Vega RB, Huss JM and Kelly DP: The coactivator PGC-1 cooperates with peroxisome proliferator-activated receptor $\alpha$ in transcriptional control of nuclear genes encoding mitochondrial fatty acid oxidation enzymes. Mol Cell Biol 20: 1868-1876, 2000

6. Wang YX, Lee CH, Tiep S, Yu RT, Ham J, Kang H and Evans RM: Peroxisome-proliferator-activated receptor $\delta$ activates fat metabolism to prevent obesity. Cell 113: 159-170, 2003.

7. Herzig S, Long F, Jhala US, Hedrick S, Quinn R, Bauer A, Rudolph D, Schutz G, Yoon C, Puigserver P, Spiegelman B and Montminy M: CREB regulates hepatic gluconeogenesis through the coactivator PGC-1. Nature 413: 179-183, 2001.

8. Yoon JC, Puigserver P, Chen GX, Donovan J, Wu ZD, Rhee J, Adelmant G, Stafford J, Kahn CR, Granner DK, Newgard CB and Spiegelman BM: Control of hepatic gluconeogenesis through the transcriptional coactivator PGC-1. Nature 413: 131-138, 2001.
9. Lin J, Wu H, Tarr PT, Zhang CY, Wu Z, Boss O, Michael LF, Puigserver P, Isotani E, Olson EN, Lowell BB, Bassel-Duby R and Spiegelman BM: Transcriptional co-activator PGC-1 $\alpha$ drives the formation of slow-twitch muscle fibres. Nature 418: 797-801, 2002.

10. St-Pierre J, Drori S, Uldry M, Silvaggi JM, Rhee J, Jäger S, Handschin C, Zheng K, Lin J, Yang W, Simon DK, Bachoo R and Spiegelman BM: Suppression of reactive oxygen species and neurodegeneration by the PGC-1 transcriptional coactivators. Cell 127: 397-408, 2006.

11. Liu C, Li S, Liu T, Borjigin J and Lin JD: Transcriptional coactivator PGC-1 $\alpha$ integrates the mammalian clock and energy metabolism. Nature 447: 477-481, 2007.

12. Knutti D, Kaul A and Kralli A: A tissue-specific coactivator of steroid receptors, identified in a functional genetic screen. Mol Cell Biol 20: 2411-2422, 2000.

13. Tcherepanova I, Puigserver P, Norris JD, Spiegelman BM and McDonnell DP: Modulation of estrogen receptor- $\alpha$ transcriptional activity by the coactivator PGC-1. J Biol Chem 275: 16302-16308, 2000.

14. Delerive P, Wu YF, Burris TP, Chin WW and Suen CS: PGC-1 functions as a transcriptional coactivator for the retinoid X receptors. J Biol Chem 277: 3913-3917, 2002.

15. Schreiber SN, Knutti D, Brogli K, Uhlmann T and Kralli A: The transcriptional coactivator PGC-1 regulates the expression and activity of the orphan nuclear receptor estrogen-related receptor $\alpha(E R R \alpha)$. J Biol Chem 278: 9013-9018, 2003.

16. Jiang WG, Douglas-Jones A and Mansel RE: Expression of peroxisome-proliferator activated receptor- $\gamma(\operatorname{PPAR}-\gamma)$ and the PPAR $\gamma$ co-activator, PGC-1, in human breast cancer correlates with clinical outcomes. Int J Cancer 106: 752-757, 2003.

17. Watkins G, Douglas-Jones A, Mansel RE and Jiang WG: The localisation and reduction of nuclear staining of PPAR $\gamma$ and PGC-1 in human breast cancer. Oncol Rep 12: 483-488, 2004.

18. Feilchenfeldt J, Bründler MA, Soravia C, Tötsch $M$ and Meier CA: Peroxisome proliferator-activated receptors (PPARs) and associated transcription factors in colon cancer: reduced expression of PPAR $\gamma$-coactivator 1 (PGC-1). Cancer Lett 203: 25-33, 2004.

19. Zhang Y, Ba Y, Liu C, Sun G, Ding L, Gao S, Hao J, Yu Z, Zhang J, Zen K, Tong Z, Xiang Y and Zhang CY: PGC-1 $\alpha$ induces apoptosis in human epithelial ovarian cancer cells through a PPAR $\gamma$-dependent pathway. Cell Res 17: 363-373, 2007.

20. Cowell RM, Talati P, Blake KR, Meador-Woodruff JH and Russell JW: Identification of novel targets for PGC- $1 \alpha$ and histone deacetylase inhibitors in neuroblastoma cells. Biochem Biophys Res Commun 379: 578-582, 2009.

21. Shiota M, Yokomizo A, Tada Y, Inokuchi J, Tatsugami K, Kuroiwa K, Uchiumi T, Fujimoto N, Seki $\mathrm{N}$ and Naito S: Peroxisome proliferator-activated receptor $\gamma$ coactivator- $1 \alpha$ interacts with the androgen receptor (AR) and promotes prostate cancer cell growth by activating the AR. Mol Endocrinol 24: 114-127, 2010.

22. Kang W, Nielsen O, Fenger C, Leslie G, Holmskov U and Reid KB: Induction of DMBT1 expression by reduced ERK activity during a gastric mucosa differentiation-like process and its association with human gastric cancer. Carcinogenesis 26: 1129-1137, 2005.

23. Kim YJ, Kwak CI, Gu YY, Hwang IT and Chun JY: Annealing control primer system for identification of differentially expressed genes on agarose gels. Biotechniques 36: 424-430, 2004.

24. Shin SW, Seo CY, Han H, Han JY, Jeong JS, Kwak JY and Park JI: $15 \mathrm{~d}_{-} \mathrm{PGJ}_{2}$ induces apoptosis by reactive oxygen speciesmediated inactivation of Akt in leukemia and colorectal cancer cells and shows in vivo antitumor activity. Clin Cancer Res 15: 5414-5425, 2009.

25. Radkov SA, Kellam P and Boshoff C: The latent nuclear antigen of Kaposi sarcoma-associated herpesvirus targets the retinoblastoma-E2F pathway and with the oncogene H-ras transforms primary rat cells. Nat Med 6: 1121-1127, 2000.

26. Valle I, Alvarez-Barrientos A, Arza E, Lamas S and Monsalve M: PGC-1 $\alpha$ regulates the mitochondrial antioxidant defense system in vascular endothelial cells. Cardiovasc Res 66: 562-573, 2005.

27. Sandberg MB, Bloksgaard M, Duran-Sandoval D, Duval C, Staels B and Mendrup S: The gene encoding acyl-CoA-binding protein is subject to metabolic regulation by both sterol regulatory element-binding protein and peroxisome proliferator-activated receptor $\alpha$ in hepatocytes. J Biol Chem 280: 5258-5266, 2005. 
28. Bhalla K, Hwang BJ, Dewi RE, Qu L, Twaddel W, Fang H, Vafai SB, Vazquez F, Puigserver P, Boros L and Girrun GD: PGC-1 $\alpha$ promotes tumor growth by inducing gene expression programs supporting lipogenesis. Cancer Res 71: 6888-6898, 2011.

29. Diplock AT, Rice-Evans CA and Burdon RH: Is there a significant role for lipid peroxidation in the causation of malignancy and for antioxidants in cancer prevention? Cancer Res 54: 1952-1965, 1994.

30. Lee JM: Inhibition of p53-dependent apoptosis by the KIT tyrosine kinase: regulation of mitochondrial permeability transition and reactive oxygen species generation. Oncogene 17: 1653-1662, 1998.

31. Guha M, Bai W, Nadler JL and Natarajan R: Molecular mechanisms of tumor necrosis factor gene expression in monocytic cells via hyperglycemia-induced oxidant stress-dependent and -independent pathways. J Biol Chem 275: 17728-17739, 2000.

32. Borboni P, Condorelli L, De Stefanis P, Sesti G and Lauro R: Modulation of insulin secretion by diazepam binding inhibitor and its processing products. Neuropharmacology 30: 1399-1403, 1991.

33. Chen ZW, Agerberth B, Gell K, Andersson M, Mutt V, Ostenson CG, Efendić S, Barros-Söderling J, Persson B and Jörnvall $\mathrm{H}$ : Isolation and characterization of porcine diazepambinding inhibitor, a polypeptide not only of cerebral occurrence but also common in intestinal tissues and with effects on regulation of insulin release. Eur J Biochem 174: 239-245, 1998.

34. Besman MJ, Yanagibashi K, Lee TD, Kawamura M, Hall PF and Shively JE: Identification of des-(Gly-Ile)-endozepine as an effector of corticotropin-dependent adrenal steroidogenesis: stimulation of cholesterol delivery is mediated by the peripheral benzodiazepine receptor. Proc Natl Acad Sci USA 86: 4897-4901, 1989.

35. Boujrad N, Hudson JR Jr and Papadopoulos V: Inhibition of hormone-stimulated steroidogenesis in cultured Leydig tumor cells by a cholesterol-linked phosphorothioate oligodeoxynucleotide antisense to diazepam-binding inhibitor. Proc Natl Acad Sci USA 90: 5728-5731, 1993.

36. Papadopoulos V and Brown AS: Role of the peripheral-type benzodiazepine receptor and the polypeptide diazepam binding inhibitor in steroidogenesis. J Steroid Biochem Mol Biol 53: 103-110, 1995.

37. Garnier M, Boujrad N, Oke BO, Brown AS, Riond J, Ferrara P, Shoyab M, Suarez-Quian CA and Papadopoulos V: Diazepam binding inhibitor is a paracrine/autocrine regulator of Leydig cell proliferation and steroidogenesis: action via peripheraltype benzodiazepine receptor and independent mechanisms. Endocrinology 132: 444-458, 1993.

38. Mukhin AG, Papadopoulos V, Costa E and Krueger KE: Mitochondrial benzodiazepine receptors regulate steroid biosynthesis. Proc Natl Acad Sci USA 86: 9813-9816, 1989.

39. Papadopoulos V, Nowzari FB and Krueger KE: Hormonestimulated steroidogenesis is coupled to mitochondrial benzodiazepine receptors. Tropic hormone action on steroid biosynthesis is inhibited by flunitrazepam. J Biol Chem 266 : 3682-3687, 1991.
40. Alho H, Varga V and Krueger KE: Expression of mitochondrial benzodiazepine receptor and its putative endogenous ligand diazepam binding inhibitor in cultured primary astrocytes and C-6 cells: relation to cell growth. Cell Growth Differ 5: 1005-1014, 1994.

41. Venturini I, Zeneroli ML, Corsi L, Baraldi C, Ferrarese C, Pecora N, Frigo M, Alho H, Farina F and Baraldi M: Diazepam binding inhibitor and total cholesterol plasma levels in cirrhosis and hepatocellular carcinoma. Regul Pept 74: 31-34, 1998.

42. Hansen JS, Faergeman NJ, Kragelund BB and Knudsen J: Acyl-CoA-binding protein (ACBP) localizes to the endoplasmic reticulum and Golgi in a ligand-dependent manner in mammalian cells. Biochem J 410: 463-472, 2008.

43. Petrescu AD, Payne HR, Boedecker A, Chao H, Hertz R, Bar-Tana J, Schroeder F and Kier AB: Physical and functional interaction of Acyl-CoA-binding protein with hepatocyte nuclear factor-4 $\alpha$. J Biol Chem 278: 1813-1824, 2003.

44. Wang L, Wei D, Huang S, Peng Z, Le X, Wu TT, Yao J, Ajani J and Xie K: Transcription factor Spl expression is a significant predictor of survival in human gastric cancer. Clin Cancer Res 9: 6371-6380, 2003.

45. Safe $\mathrm{S}$ and Abdelrahim M: Sp transcription factor family and its role in cancer. Eur J Cancer 41: 2438-2448, 2005.

46. Yao JC, Wang L, Wei D, Gong W, Hassan M, Wu TT, Mansfield $\mathrm{P}$, Ajani $\mathrm{J}$ and Xie K: Association between expression of transcription factor $\mathrm{Spl}$ and increased vascular endothelial growth factor expression, advanced stage, and poor survival in patients with resected gastric cancer. Clin Cancer Res 10: 4109-4117, 2003.

47. Yuan P, Wang L, Wei D, Zhang J, Jia Z, Li Q, Le X, Wang H, Yao $\mathrm{J}$ and Xie K: Therapeutic inhibition of Sp1 expression in growing tumors by mithramycin A correlates directly with potent antiangiogenic effects on human pancreatic cancer. Cancer 110: 2682-2690, 2007

48. Jiang Y, Wang L, Gong W, Wei D, Le X, Yao J, Ajani J, Abbruzzese JL, Huang S and Xie K: A high expression level of insulin-like growth factor 1 receptor is associated with increased expression of transcription factor Sp1 and regional lymph node metastasis of human gastric cancer. Clin Exp Metastasis 21: 755-764, 2004.

49. Lou Z, O'Reilly S, Liang H, Maher VM, Sleight SD and McCormick JJ: Down-regulation of overexpressed sp1 protein in human fibrosarcoma cell lines inhibits tumor formation. Cancer Res 65: 1007-1017, 2005.

50. Nenoi M, Ichimura S, Mita K, Yukawa O and Cartwright IL: Regulation of the catalase gene promoter by Sp1, CCAATrecognizing factors, and a WT1/Egr-related factor in hydrogen peroxide-resistant HP 100 cells. Cancer Res 61: 5885-5894, 2001.

51. Dhar SK, Xu Y, Chen Y and St Clair DK: Specificity protein 1-dependent p53-mediated suppression of human manganese superoxide dismutase gene expression. J Biol Chem 281: 21698-21709, 2006. 